\title{
Relationship between Peripheral Blood Parameters and Stage and Grade of Disease in Patients with Urothelial Cancer of the Urinary Bladder
}

\author{
Ayman Kassem, Ashraf Mosharafa, Bashar Alabdou* and Ashraf Abulela \\ Department of Urology, Cairo University, Egypt
}

Submission: November 23, 2016; Published: January 09, 2017

*Corresponding author: Bashar Alabdou, Department of Urology, Cairo University, Egypt, Email: drbashar.alabdou@gmail.com

Abstract
Various researchers reported relationships between peripheral blood parameters and different solid tumors' stage and prognosis. The
current study aims to assess the relationship between peripheral blood parameters and stage and grade of disease in patients with urothelial cancer of the urinary bladder (Figure 1).

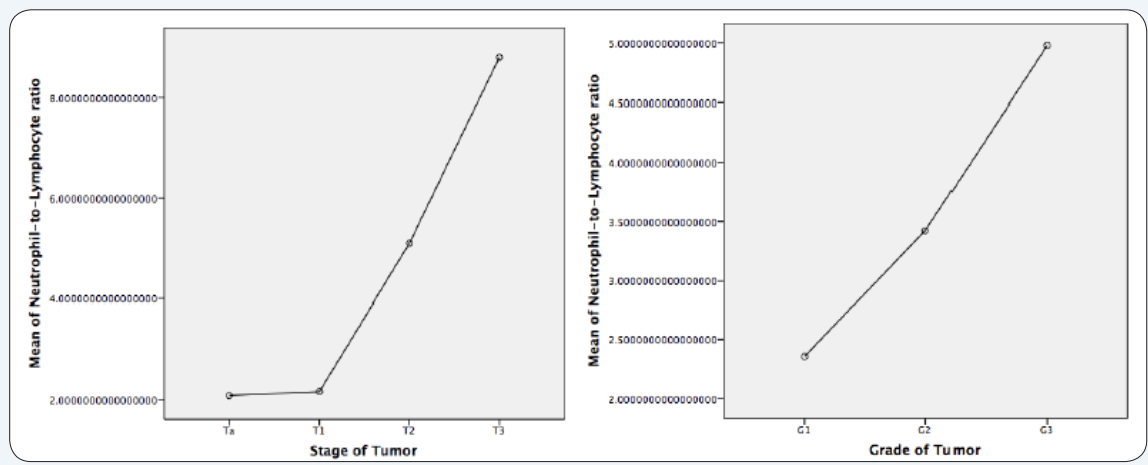

Methods: 102 patients diagnosed with bladder cancer were enrolled in this prospective cohort study. Preoperative blood samples were taken before the first cystoscopic examination. Patients were grouped as having a non-muscle-invasive (NMIBC) or muscle-invasive urothelial carcinoma (MIBC). The predictive value of various blood parameters (Hb, Total Leucocytic Count (TLC), Neutrophil-Lymphocyte Ratio, and platelet count) for bladder cancer stage and grade were evaluated.

Results: 49 patients had NMIBC including 20 (19.6\%) with Ta disease and 29 (28.4\%) with T1 disease. The 53 patients with MIBC, 40 (39.2\%) had T2 disease and $13(12.7 \%)$ had T3 disease. While, G1=22 (21.6\%), G2=18 (17.6\%) and G3=62 (60.8\%). TLC was significantly lower in stage Ta compared to stagesT2 and T3 ( $<<0.003)$, as well as in grades G1 and G2 compared to G3 tumors ( $\mathrm{p}<0.05)$. Platelet count was not significantly associated with tumor stage $(\mathrm{p}>0.05)$, but showed association with tumor grade, specifically G2 vs. G3 ( $p=0.005)$. The values of neutrophil, lymphocyte count and neutrophil-to-lymphocyte ratio showed statistically significant differences between different tumor stages and grades $(\mathrm{p}<0.005)$.

Conclusions: Peripheral blood parameters may play a role in predicting stage and grade of urinary bladder cancer and may be used as adjunct to clinical, radiological and pathological findings in disease evaluation.

Keywords: Urinary bladder cancer; Peripheral blood parameters; Tumor stage; Taumor grade

Abbreviations: CRP: C-reactive Protein; ESR: Erythrocyte Sedimentation Rate; HB: Hemoglobin; HIV: Human Immunodeficiency Virus; IL-1: Interleukin-1; ISUP: International Society of Urologic Pathology; MIBC: Muscle Invasive Bladder Cancer; NF-kB: Nuclear Factor-KappaB; NLR: Neutrophil-to-Lymphocyte Ratio; NMIBC: Non-Muscle Invasive Bladder Cancer; SCC: Squamous Cell Carcinoma; TCC: Transitional Cell Carcinoma; TNF: Tumor Necrosis Factor; TNM: Classification of Malignant Tumor (Tumor, Node, Metastasis); TURBT: Transurethral Resection of the Bladder Tumor; UC: Urothelial Carcinoma; UICC: Union International Contre Le Cancer; UTI: Urinary Tract Infection; VEGF: Vascular Endothelian Growth Factor; WBC: White Blood Cells; WHO: World Health Organization 


\section{Introduction}

Bladder cancer is a common tumor in the urinary tract and is the ninth most prevalent cancer around the world [1]. Approximately $90 \%$ of bladder cancers are urothelial carcinomas (UC) and $75-85 \%$ of UC are non-muscle invasive while $15-25 \%$ is invasive. Treatment of UC depends on pathological behavior of the tumor. Non-muscle-invasive tumors can be removed by transurethral resection but recurrence is common [2]. Two main types of bladder cancer are identified: the transitional cell carcinomas (TCC), related to cigarette smoking and most prevalent in Western and industrialized countries, and the squamous cell carcinomas (SCC), which are more frequently seen in some Middle Eastern and African countries, where urinary schistosomiasis is an endemic disease. Rare types of bladder cancer include small cell carcinoma, carcinosarcoma, primary lymphoma, and sarcoma [3]. In the United States, bladder cancer is nearly three times more common among men than woman. In men, it is the fourth most common cancer, after prostate, lung and colorectal cancer, accounting for $5.5 \%$ of all cancer cases. In women, it is the eighth most common cancer, accounting for $2.3 \%$ of all cancer [4]. In western countries, more than $90 \%$ of bladder cancers are transitional cell carcinomas, $80 \%$ are papillary and $20 \%$ are solid and invasive. Squamous cell carcinoma accounts for only 1\% of bladder cancer in England [5] and 3-7\% in the United States [6].

The classic presentation of bladder cancer is painless gross hematuria, which is seen in approximately $80-90 \%$ of patients. Physical examination results are often unremarkable. Cytology, Cystoscopy and biopsy are the principal diagnostic tests [7]. The host inflammatory response has gained increasing attention in oncology research. Infiltrating cells of the immune system are constituents of virtually all neoplasms [8]. While initially thought to represent an antitumoral response, immune cells, particularly those of the innate immune system, also exhibit effects that promote carcinogenesis and cancer progression [8-9]. Proposed mechanisms include increased supply of growth factors, survival factors, pro-angiogenic factors, extracellular matrix-modifying enzymes (which can facilitate invasion and metastasis) and inductive signals that may lead to epithelial-to-mesenchymal transition [8]. Thus, there is a biological rationale for using NLR, the ratio of circulating neutrophils (immune cells of the innate system) to lymphocytes (immune cells of the adaptive system), as a measure of the systemic host response when evaluating the association between inflammation and cancer outcomes. The prognostic role of NLR has been evaluated in numerous epidemiologic studies of various cancer types. Higher NLR has been found to be consistently associated with more advanced stage and more aggressive tumor behaviour [10-11].

\section{Aim of the Study}

To assess the relationship between peripheral blood parameters and stage and grade of disease in patients with urothelial cancer of the urinary bladder.

\section{Pathology of Cancer Bladder}

\section{Normal Bladder Urothelium}

The wall of the urinary bladder consists of four layers.

Urothelium: The urothelium is the innermost epithelial lining of the bladder. The urothelium is the site of origin for urothelial carcinomas (Figure2).

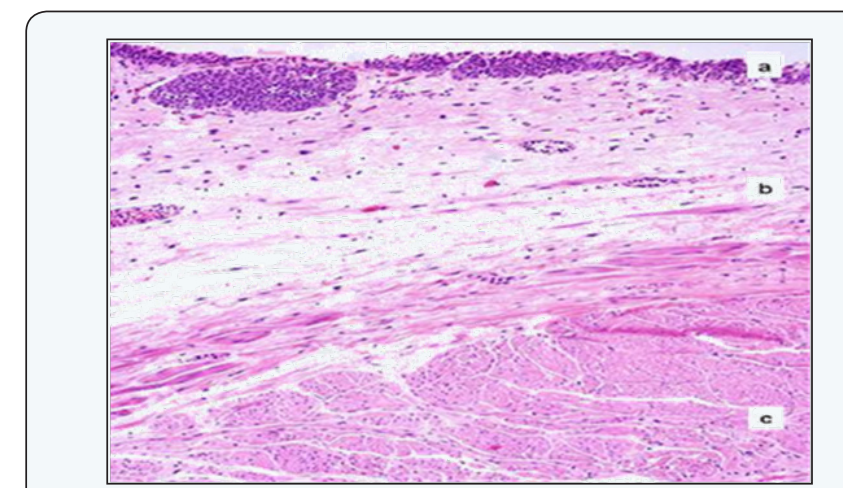

Figure 2: Normal urinary bladder histology: urothelium (a); lamina propria (b) with muscularis mucosae and submucosa; and muscularis propria (detrusor muscle) (c).Courtesy of Cristina Magi-Galluzzi, MD, PhD.

Lamina propria: The lamina propria is separated from the urothelium by a thin basement membrane that is composed of abundant connective tissue containing vascular and neuronal structures. Fascicles of smooth muscle can be found within the superficial lamina propria, either isolated or forming complete or incomplete muscularis mucosae [12-13].

Muscularis propria: The muscularis propria (detrusor muscle) surrounds the lamina propria and consists of thick, irregularly arranged muscle bundles. In small biopsies, fascicles of muscle in the lamina propria may be confused with the larger smooth muscle bundles of the muscularis propria, potentially resulting in an error in tumor staging. Adipose tissue also can be present within the lamina propria and/or muscularis propria. The presence of invasive tumor in fat thus is not always indicative of extravesical extension [14].

Adventitia or serosa: The muscularis propria is separated from the surrounding tissues by a serosal layer [13-14].

\section{Pre-Neoplastic Proliferative Abnormalities}

A variety of changes can occur in the urothelium in response to inflammation and irritation or carcinogens. These changes may be proliferative, metaplastic or both.

Epithelial hyperplasia: The term epithelial hyperplasia is used to describe non-neoplastic increase in the number of transitional epithelial stratification beyond the normal value of 6 cell layers without nuclear or architectural abnormalities. Increase of about 15 to 20 layers may occur in bilharzial bladder. But the urothelium retains its flat topography without exophytic or endophytic folding. The transitional cells are regular and show normal polarity. The nuclei are relatively small, of uniform size and density. 
Von Brunn 's Nests: Von Brunn $=$ s are islands of benign appearing urothelium situated in the lamina propria. These are believed to result from inward proliferation of the basal cells. Brunn's nests may either be solid or contain a central slit like lumen, lined by transitional cells. In the bilharzial urologic series of Zahran and associates, this change was observed in 53.4\% of cases (Figure 3).

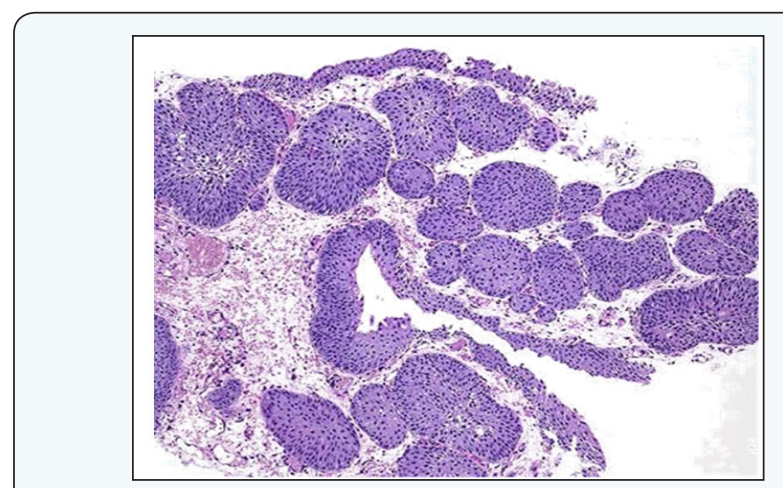

Figure 3: Von Brunn's nests.

Cystitis cystica: Cystitis cystica is similar to Von Brunn's nests except that the center of the nests of urothelium has undergone eosinophilic liquefication. Cystitis cystica is present in $60 \%$ of normal bladder autopsies. It should be distinguished from cystitis follicularis, which is non-neoplastic response to chronic bacterial infection. Grossly, it appears as punctuate yellow submucosal nodule (Figure 4).
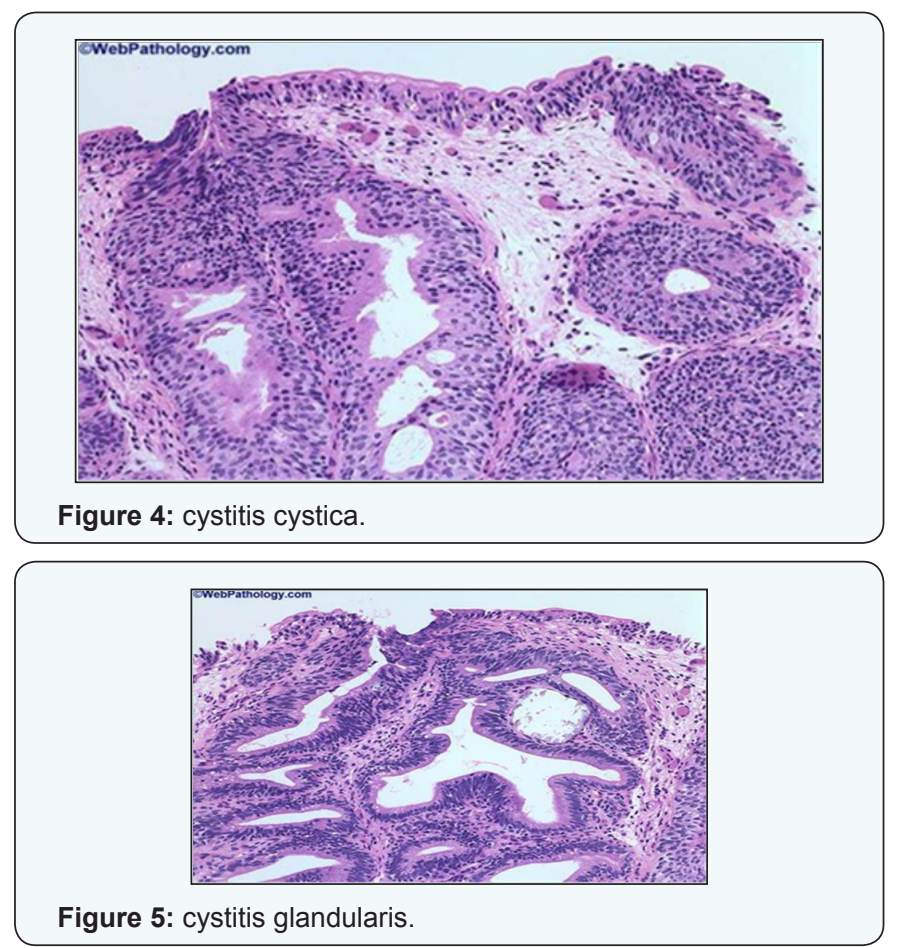

Cystitis glandularis: Cystitis glandularis is similar to cystitis cystica except that the transitional cells have undergone glandular metaplasia. It appears histologically as submucosal nests of columnar epithelial cells surrounding a central liquefied region of cellular degeneration [15]. Two cell types may be recognized according to cytoplasmic features, namely: an eosinophilic cell type and a mucinous or goblet cell type. Usually one cell type predominates, but at times they occur together in the lesion. The predominance of the mucinous cell type produces glandular structures indistinguishable from those of colonic mucosa. Cystitis glandularis may be a precursor of adenocarcinoma [16] (Figure 5).

Atypical hyperplasia: Atypical hyperplasia is similar to epithelial hyperplasia except that there are also nuclear abnormalities and partial derangement of umbrella cell layer [17]. In patients with superficial bladder cancers, the presence of atypia in adjacent urothelium is associated with a $35 \%$ to $40 \%$ risk of developing invasive disease [18].

Urothelial metaplasia: Urothelial metaplasia refers to the bladder lining, often in focal areas, demonstrating a nontransitional epithelial appearance, usually with epidermoid (squamous metaplasia) or glandular (adenomatous metaplasia) development.

Vesical leukoplakia: Leukoplakia is characterized by squamous metaplasia with marked keratinization, downward growth of rete pegs (acanthosis), cellular atypia, and dysplasia. It is believed to be a response of the normal urothelium to noxious stimuli and is generally considered a premalignant lesion that may progress to SCC in up to $20 \%$ of patients.

Dysplasia: It is a term, which denotes epithelial changes that are intermediate between normal urothelium and carcinoma in situ. There are three categories of dysplasia: mild, moderate, and severe. Dysplastic cells have large, round, notched, basely situated nuclei that do not exhibit the normal epithelial polarity. Dysplastic epithelium does not have an increased number of cell layers or mitotic figures [19].

Carcinoma in situ: Carcinoma in situ refers to flat areas of epithelium composed of cells with anaplastic features and a disorderly pattern of growth without extension into the bladder lumen or penetration of the basement membrane. The cells show a severe degree of anaplasia, abundant mitotic figures, and a loss of cell cohesiveness. The number of cell layers in carcinoma in situ may be normal or increased with no formation of papillary structures (Figure 6).

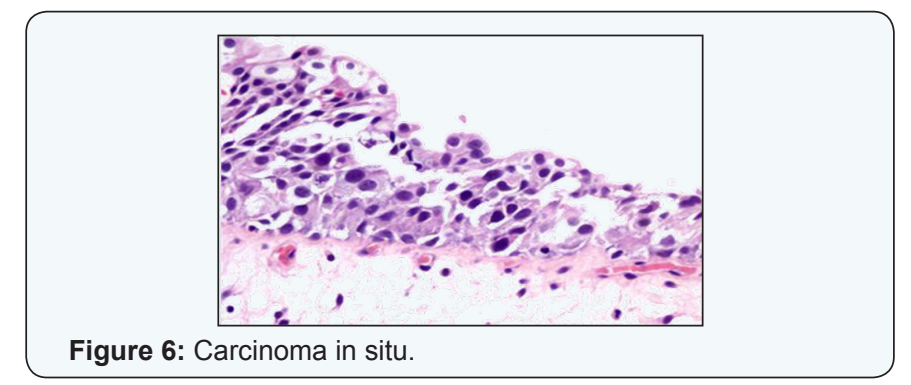

\section{Transitional cell carcinoma}

Transitional cell carcinoma differs from normal urothelium by having an increased number of epithelial cell layers with 
papillary folding of the mucosa, loss of cell polarity, abnormal cell maturation from the basal to superficial layers, giant cells, nuclear crowding, increased nuclear to cytoplasmic ratio, prominent nucleoli, clumping of chromatin and increased number of mitoses. The significant criteria are the prominent nucleoli, clumping of chromatin, increased cell layers and loss of cell polarity. Urothelial carcinomas demonstrate a variety of patterns of tumor growth, including papillary, sessile, infiltrating, nodular, mixed, and flat intraepithelial growth (carcinoma in situ). Urothelium has great metaplastic potential; therefore, urothelial carcinomas may contain spindle cell, squamous, or adenocarcinomatous elements. These elements are present in about one third of muscle-invasive urothelial bladder cancers, and several may be exhibited in a single cancer. Approximately $70 \%$ of bladder tumors are papillary, $10 \%$ are nodular, and $20 \%$ are mixed [14], (Figure 7).

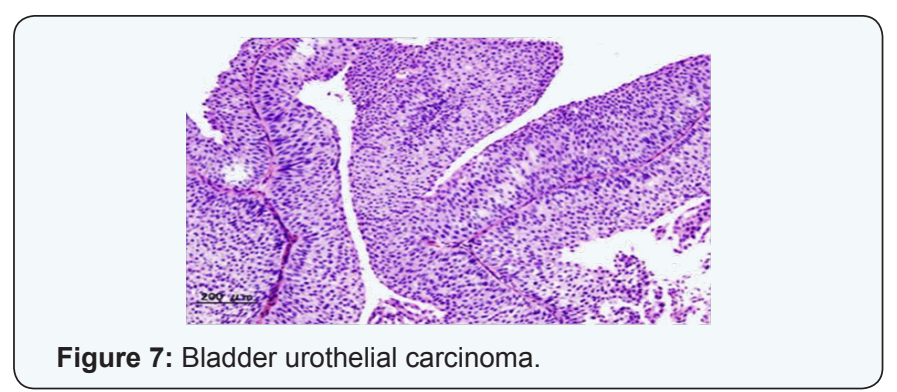

\section{Tumor grading}

Several systems have been used to grade and classify bladder neoplasms. The system proposed by the World Health Organization (WHO) in 1973 distinguished papillomas from grades I, II, and III papillary transitional cell carcinomas (TCCs) [20]. In 1998, the WHO and ISUP published a consensus classification system for urothelial (transitional cell) neoplasms [14]. The clinical significance of this system was validated by subsequent studies, and in 2004, it was accepted as the standard classification system [21]. According to this system, urothelial cancer is classified as low-grade and high-grade based upon the degree of nuclear anaplasia and architectural abnormalities. "Well-differentiated tumors" have a thin fibrovascular stalk with a thickened urothelium containing more than seven cell layers, with cells exhibiting only slight anaplasia and pleomorphism.

The disturbance of the base-to-surface cellular maturation is mild, and there are only rare mitotic figures. Lesions with this appearance (similar to those formerly called grade 1) are urothelial cancers [22]. "Moderately differentiated (low grade urothelial carcinoma) tumors" have a wider fibrovascular core, a greater disturbance of the base-to-surface cellular maturation, and a loss of cell polarity. The nuclear-cytoplasmic ratio is higher, with more nuclear pleomorphism and prominent nucleoli. Mitotic figures are more frequent. These have been termed low-grade urothelial carcinomas in the new WHO and ISUP classification Murphy and colleagues (2002) point out the difficulties for even experienced practitioners to distinguish between low malignant potential and low-grade carcinoma lesions as defined in the current classification [14]. Poorly differentiated tumors, named high-grade urothelial carcinoma in the new WHO and ISUP system (old grade 3), have cells that do not differentiate as they progress from the basement membrane to the surface (Table 1). Marked nuclear pleomorphism is noted, with a high nuclear-cytoplasmic ratio [14].

Table 1: WHO grading 1973 and 2004. ISUP: International Society of Urologic Pathology.

\begin{tabular}{|c|c|}
\hline 2004 WHO/ISUP classification & $\begin{array}{c}\text { WHO 1973 } \\
\text { Classification }\end{array}$ \\
\hline $\begin{array}{c}\text { Papillary urothelial neoplasm of low } \\
\text { malignant potential }\end{array}$ & Grade 1 \\
\hline Low-grade papillary urothelial carcinoma & Grade 1; Grade 2 \\
\hline High-grade papillary urothelial carcinoma & Grade 2; Grade 3 \\
\hline Carcinoma in situ & Carcinoma in situ \\
\hline $\begin{array}{c}\text { Abbreviation: ISUP, International Society of } \\
\text { Urologic Pathologists. }\end{array}$ \\
\hline
\end{tabular}

TNM classification approved by the Union International Contre le Cancer (UICC), has been widely accepted.

\section{Staging system}

TNM classification approved by the Union International Contre le Cancer (UICC), has been widely accepted (Table 2), (Figure 8).

Table 2: 2009 TNM classification of urinary bladder cancer.

\begin{tabular}{|c|}
\hline T - Primary tumor \\
\hline $\begin{array}{l}\text { TX Primary tumor cannot be assessed T0 No evidence of primary } \\
\text { tumor }\end{array}$ \\
\hline $\begin{array}{l}\text { Ta Non-invasive papillary carcinoma Tis Carcinoma in situ: flat } \\
\text { tumor }\end{array}$ \\
\hline T1 Tumor invades subepithelial connective tissue \\
\hline T2 Tumor invades muscle \\
\hline $\begin{array}{c}\text { T2a Tumor invades superficial muscle (inner half) T2b Tumor } \\
\text { invades deep muscle (outer half) }\end{array}$ \\
\hline T3 Tumor invades perivesical tissue T3a Microscopically \\
\hline T3b Macroscopically (extravesical mass) \\
\hline $\begin{array}{l}\text { T4 Tumor invades any of the following: prostate, uterus, vagina, } \\
\text { pelvic wall, abdominal wall }\end{array}$ \\
\hline $\begin{array}{l}\text { T4a Tumor invades prostate, uterus or vagina T4b Tumor invades } \\
\text { pelvic wall or abdominal wall }\end{array}$ \\
\hline $\mathrm{N}$ - Lymph nodes \\
\hline $\begin{array}{c}\text { NX Regional lymph nodes cannot be assessed N0 No regional lymph } \\
\text { node metastasis }\end{array}$ \\
\hline $\begin{array}{l}\text { N1 Metastasis in a single lymph node in the true pelvis (hypogastric, } \\
\text { obturator, external iliac or presacral) }\end{array}$ \\
\hline $\begin{array}{l}\text { N2 Metastasis in multiple lymph nodes in the true pelvis } \\
\text { (hypogastric, obturator, external iliac, or presacral) }\end{array}$ \\
\hline N3 Metastasis in common iliac lymph node(s) \\
\hline M - Distant metastasis \\
\hline MX Distant metastasis cannot be assessed M0 No distant metastasis \\
\hline M1 Distant metastasis \\
\hline
\end{tabular}




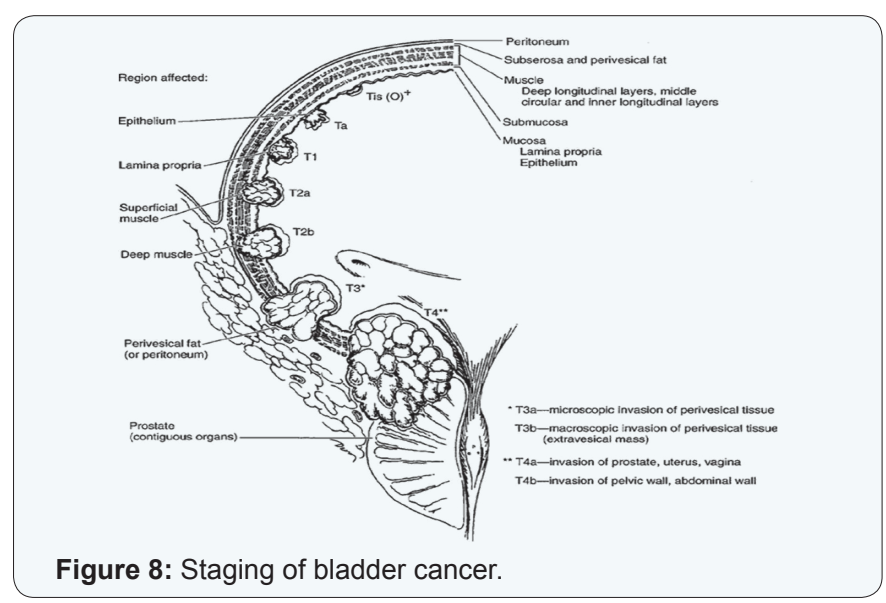

\section{Squamous cell carcinoma}

Bilharzial SCCs are exophytic, nodular, fungating lesions that are usually well differentiated and have a relatively low incidence of lymph node and distant metastases. Whether the low incidence of distant metastases is due to capillary and lymphatic fibrosis resulting from chronic schistosomal infection [23] or to the relatively low histologic grade [22] of these tumors is not clear.

Non-bilharzial SCCs are usually caused by chronic irritation from urinary calculi, long-term indwelling catheters, chronic urinary infections, or bladder diverticula. As many as $80 \%$ of paraplegics with chronic infections and/or indwelling catheters have squamous changes in the bladder, and about $5 \%$ develop SCC [24]. Cigarette smoking has also been reported to be significantly associated with an increased risk of bladder SCC [25]. In general, its prognosis is poor because most patients have advanced disease at the time of diagnosis (Figure 9).

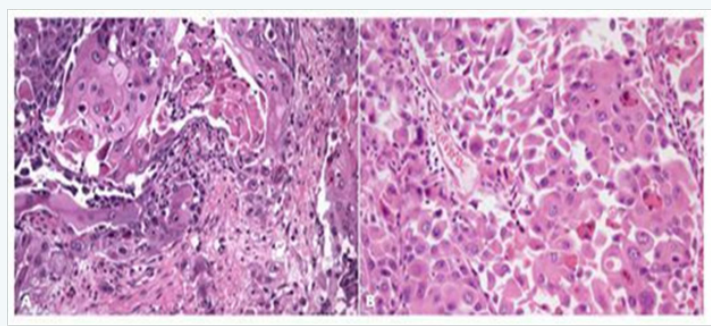

Figure 9: Squamous cell carcinoma.

\section{Verrucous squamous cell carcinoma}

This is a rare variant of squamous cell carcinoma of the bladder, accounting for less than $5 \%$ of cases. Most cases are associated with S. haematobium infection; few cases have been reported from nonendemic areas. The tumor has an indolent growth pattern and spreads by direct extension. It does not metastasize, although it may develop foci of invasive SCC [2627].

\section{Grading of squamous cell carcinoma}

The tumor is generally graded as well, and moderately or poorly differentiated, depending upon the extent of keratinization and nuclear pleomorphism. However, the grading system is not universally reproducible, as some authors believe that there is no direct correlation between the aggressiveness and the tumor grade [28]. Others believe that histologic grade influences the tumor stage and clinical Outcome [29].

\section{Adenocarcinoma}

Adenocarcinomas account for less than 2\% of primary bladder cancer [25], (Figure 9). They are classified into three groups: (a) primary vesical; (b) urachal; and (c) metastatic [30]. Adenocarcinomas also occur in intestinal urinary conduits, augmentations, pouches, and ureterosigmoidostomies (Figure 10).

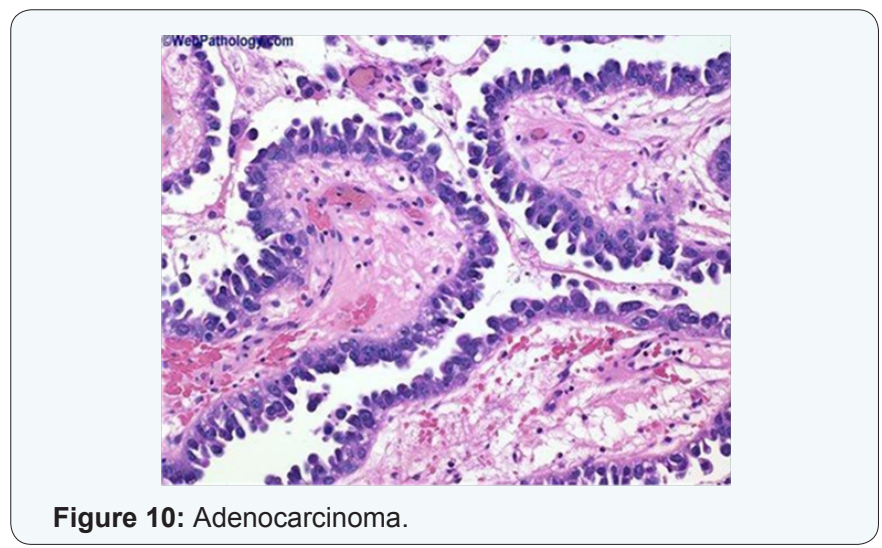

\section{Primary vesical adenocarcinoma}

Adenocarcinomas usually arise in the bladder base area or in the dome, but they can occur anywhere. It is the most common type of cancer in exstrophic bladders. These tumors develop in response to chronic inflammation and irritation [31]. All histologic variants of enteric adenocarcinoma occur in the bladder. Most adenocarcinomas are poorly differentiated and invasive. They are more commonly associated with cystitis glandularis than with carcinoma in situ.

\section{Urachal carcinoma}

Urachal carcinomas are extremely rare tumors that arise outside the bladder, and they are usually adenocarcinomas, although they may be primary TCCs or SCCs and, rarely, even sarcomas. Urachal carcinomas have a sharp demarcation between the tumor and the adjacent bladder epithelium, with the tumor being located in the bladder wall beneath the normal epithelium. They may appear with a bloody or mucoid discharge from the umbilicus or produce a mucocele, occurring as a palpable mass. Tumors invading the bladder lumen may produce mucus in the urine. Patients with urachal carcinomas have a worse prognosis than do those with primary bladder adenocarcinomas [15]. Histologically, these tumors exhibit wider and deeper infiltration of the bladder wall than expected, compromising the results of partial cystectomy. Urachal carcinomas metastasize to iliac and inguinal lymph nodes, omentum, liver, lung and bone. 


\section{Metastatic adenocarcinoma}

One of the most common forms of adenocarcinoma of the bladder is metastatic (or invasive) adenocarcinoma [32]. The primary sites for these tumors include the rectum, stomach, endometrium, breast, prostate, and ovary.

\section{Values of peripheral blood parameters in NMIBC and MIBC}

Hemoglobin (Hb): The most common primary symptom of bladder cancer is painless hematuria $(80-90 \%$ of patients) and gross hematuria more commonly predicts bladder cancer than does microscopic hematuria [33]. The anemia of cancers is caused by stimulation of the cellular immune system and inflammatory changes, which stimulate the production of chemicals called cytokines and affect both red cell production and survival. Several cytokines, including tumor necrosis factor (TNF), Interferon Gamma and Interleukin-1 (IL-1), can suppress bone marrow production (erythropoiesis) by affecting red cell production [34].

White blood cells and the platelets counts: White blood cells (WBCs), also called leukocytes or leucocytes, are the cells of the immune system that are involved in protecting the body against both infectious disease and foreign invaders [35]. The most frequent systemic alterations detected in patients with malignant solid tumors are leukocytosis and neutrophilia. These hematological conditions are significantly correlated with advanced disease and, consequently, with poor prognosis. Leukocytosis is a condition often encountered in a clinical setting, usually caused by an increase in the number of neutrophils, which represent 50 to $60 \%$ of total leukocytes [36]. Platelets, also called thrombocytes, are a component of blood whose function (along with the coagulation factors) is to stop bleeding by clumping and clotting blood vessel injuries [37]. Thrombocytosis is commonly observed in neoplastic diseases. Elevated levels of platelet counts may be associated with tumor progress. Various studies have showed that thrombocytosis is associated with poor prognosisin ovarian cancer renal cell carcinoma [38], colorectal cancer [39], gastric cancer [40], and endometrial carcinomas [41].

Neutrophil-to-lymphocyte ratio: In medicine neutrophil to lymphocyte ratio (NLR) is used as a marker of subclinical inflammation. It is calculated by dividing the number of neutrophils by number of lymphocytes, usually from peripheral blood sample [42]. The neutrophil and lymphocyte counts play important roles in systemic inflammation. The neutrophil count is increased by anti-apoptotic markers that affect tumor growth and progression $(\mathrm{NF}-\mathrm{\kappa B})$, growth factors, and proangiogenic factors (VEGF) [43].

The lymphocytic response is the main component in the control of cancer progression. Lymphocytopaenia leads to a decrease in the cellular immune response. While some studies have reported that decreased T-cell activity inside the tumor speeds up primary tumor progression, other studies have shown a link between lymphocytes and the cell-mediated response with respect to tumor infiltration. Additionally, a low level of lymphocytic infiltration at tumor margins indicates a poor prognosis. The fact that the NLR indicates only part of the inflammatory response somewhat limits its value as a marker. However, the NLR is still a convenient, inexpensive, and reproducible parameter that demonstrates the link between inflammation and tumor development.

Neutrophil to lymphocyte ratio is associated with different types of cancer. Increased pretreatment NLR is associated with poor prognosis in colorectal, gastric, and ovarian cancer; malignant mesothelioma; and renal cell carcinoma [44-45] in their study, stated that, NLR threshold value $<2.5$ and $\geq 2.5$ as an independent prognostic factor, likewise tumor size, hydronephrosis, $\mathrm{Hb}$ levels, and the combination of these factors, could stratify disease-specific survival (DSS) risks in bladder cancer patients treated with radical cystectomy .

\section{Some Clinical Studies on the Prognostic Value of NLR in UC of the Bladder}

\section{Patients and methods}

The study design is a prospective cohort study includes 102 patients who were diagnosed with urothelial cancer of the urinary bladder between October 2015 and April 2016. The study was done at the Department of Urology, Cairo University. Preoperative blood sample were taken before the first cystoscopic examination (complete blood picture with differential). The stage and grade of the disease were recorded from pathology reports (Table 3).

Table 3: Clinical studies on the prognostic value of NLR in UC of the bladder.

\begin{tabular}{|c|c|c|c|c|c|c|}
\hline Study & Marker & $\begin{array}{c}\text { Publication } \\
\text { year }\end{array}$ & $\begin{array}{c}\text { Number of } \\
\text { patients(NMIBC/ } \\
\text { MIBC) }\end{array}$ & Threshold & $\begin{array}{c}\text { Assessment } \\
\text { period }\end{array}$ & Main findings \\
\hline $\begin{array}{c}\text { Demirtas, et al. } \\
{[40]}\end{array}$ & NLR & 2013 & $201(35 / 166)$ & 2.5 & Before RC & $\begin{array}{c}\text { Evaluated NLR (>2.5) was not associated overall } \\
\text { survival }\end{array}$ \\
\hline $\begin{array}{c}\text { Harmanns, et } \\
\text { al. [41] }\end{array}$ & NLR & 2014 & 424 & 3 & Before RC & $\begin{array}{c}\text { Patients with elevated NLR (>3) significantly } \\
\text { showed more advance pathologic tumor stage. } \\
\text { Elevated NLR (>3) was significantly associated } \\
\text { with RFS, OS and CSS }\end{array}$ \\
\hline
\end{tabular}




\begin{tabular}{|c|c|c|c|c|c|c|}
\hline $\begin{array}{c}\text { Kaynar, et al. } \\
{[42]}\end{array}$ & NLR & 2014 & 291(192/99) & $\begin{array}{c}\text { NA } \\
\text { (continuous) }\end{array}$ & $\begin{array}{l}\text { 1day before } \\
\text { surgery } \\
\text { (TURBT or } \\
\text { RC) }\end{array}$ & $\begin{array}{c}\text { Patients with MIBC showed significantly higher } \\
\text { NLR value then those with NMIBC. Also higher } \\
\text { NLR significantly correlated with advanced } \\
\text { age, larger tumor size, and aggressive tumor } \\
\text { invasiveness }\end{array}$ \\
\hline $\begin{array}{l}\text { Potretzke, et } \\
\text { al. [43] }\end{array}$ & NLR & 2014 & $102(31 / 71)$ & $\begin{array}{c}\text { NA } \\
\text { (continuous) }\end{array}$ & Before RC & $\begin{array}{l}\text { NLR was significant predictor of the } \\
\text { pathological upstaging after RC; also, patients } \\
\text { with pathological upstaging to }>\text { pT3 had a } \\
\text { significantly greater NLR compare to patients } \\
\text { who remained at }<\text { pT2 }\end{array}$ \\
\hline $\begin{array}{c}\text { Viers, et al. } \\
{[44]}\end{array}$ & NLR & 2014 & $899(392 / 507)$ & 2.7 & $\begin{array}{c}\text { Within } 90 \\
\text { days RC }\end{array}$ & $\begin{array}{c}\text { Evaluated NLR (>2.5) was significantly } \\
\text { associated with adverse pathologic funding } \\
\text { (high pathologic tumor stage, node positive and } \\
\text { large tumor size); increased NLR (continuous) } \\
\text { independently associated with worse RFS, OS, } \\
\text { and CSS }\end{array}$ \\
\hline $\begin{array}{c}\text { Mano, et al. } \\
{[47]}\end{array}$ & NLR & 2015 & $107(107 / 0)$ & $\begin{array}{l}2.41 \text { (for } \\
\text { progression } \\
\text { ) } 2.43 \text { (for } \\
\text { recurrence) }\end{array}$ & $\begin{array}{l}\text { Before } \\
\text { TURBT }\end{array}$ & $\begin{array}{c}\text { Elevated NLR }(>2.41) \text { showed more pT1 tumors } \\
\text { and was significantly associated with disease } \\
\text { progression; evaluated NLR }(>2.43) \text { was } \\
\text { independent predictor of disease recurrence }\end{array}$ \\
\hline $\begin{array}{c}\text { Seah, et al. } \\
{[48]}\end{array}$ & NLR & 2015 & $26(26 / 0)$ & NA & $\begin{array}{l}\text { Before } \\
\text { NACH, } \\
\text { during } \\
\text { NACH and } \\
\text { after RC }\end{array}$ & $\begin{array}{l}\text { Significant NLR decrease from before NACH } \\
\text { to before RC was observed in patients with } \\
\text { pathological response after NACH and RC }\end{array}$ \\
\hline $\begin{array}{c}\text { Kang, et al. } \\
{[45]}\end{array}$ & NLR & 2015 & 385 & $\begin{array}{l}2.0 \\
\text { (Postoperative) } \\
2.1 \\
\text { (preoperative) }\end{array}$ & $\begin{array}{l}\text { Within } \\
1 \text { month } \\
\text { before RC } \\
\text { Within } 3 \\
\text { months after } \\
\text { RC }\end{array}$ & $\begin{array}{l}\text { Patients with elevated postoperative NLR }(>2.0) \\
\text { had higher rates of }>\text { pT3, LVI, and positive } \\
\text { lymph node and elevated postoperative NLR } \\
(>2.0) \text { was an independent predictor of OS and } \\
\text { CSS; also patients with preoperative continuous } \\
\text { elevated NLR }(2.1->2.0) \text { showed worse OS and } \\
\text { CSS compared with other change groups }\end{array}$ \\
\hline
\end{tabular}

NLR: Neutrophil-to-Lymphocyte Ratio, TURBT: Transurethral Resection of Bladder Tumor, RC: Radical Cystectomy, NACH: Neo Adjuvant Chemotherapy, NMIBC: Non muscle Invasive Bladder Cancer, OS: Overall Survival, DSS: Disease Specific Survival, RFS: Recurrence -Free Survival, and CSS: Cancer Specific Survival.

\section{Inclusion criteria}

Patients who were diagnosed with urothelial cancer of the urinary bladder and admitted to the Urology Department at Kasr Alainy Hospitals.

\section{Exclusion criteria}

1. Patients who had pyelonephritis, prostatitis, epididymoorchitis or patients with fever.

2. Hematologic disease (myeloma, leukemia, lymphoma).

3. Secondary malignancy.

4. Patients who had a history of conditions that may have influenced blood cell lines (connective tissue disease, malignant lymphoma, leukaemia and HIV infection).

\section{Methodology in Details}

Preoperative blood samples were taken before the first cystoscopic examination from patients who diagnosed with urothelial cancer of the urinary bladder to make assessment relationship between peripheral blood parameters and stage and grade of the disease in patients with urothelial cancer of urinary bladder. Patients were grouped as having a non-muscle- invasive or muscle-invasive urothelial carcinoma. The stage and grade of the disease were recorded from pathology reports.

A standard form was designed and included the following:

\section{1-Name:}

\section{2-Gender:}

3-Age:

\section{4-Diagnosis, including stage and grade:}

5- Peripheral blood parameters: hemoglobin ( $\mathrm{Hb})$, white blood cells (WBCs), neutrophil count, lymphocyte count, neutrophil-to-lymphocyte ratio and platelets count.

\section{Statistical Methods}

Data management and analysis were performed using SigmaStat program; version 3.5 (Systat Software, Inc., USA). The graphs were done using Microsoft Excel 2007. The numerical data were statistically presented in terms of range, mean, standard deviation, median and interquartile range. Categorical data were summarized as percentages. All p-values are considered significant when P-values were less than 0.05 . 


\section{Results}

A total of 102 patients were included in the study, 49 NMIBC and 53 MIBC, prospectively. The majority of the patients were male $(97$ of $102,95.1 \%)$, with a median age of 59 years of the NMIBC patients, 20 (19.6\%) had Ta disease and 29 (28.4\%) had
T1 disease. Of the MIBC patients, 40 (39.2\%) had T2 disease and $13(12.7 \%)$ had T3 disease. While, G1=22 (21.6\%), G2=18 $(17.6 \%)$ and $G 3=62(60.8 \%)$. Full blood count samples were taken prior to TURBT surgery. The value of hemoglobin showed no statistically significant associations $(\mathrm{p}>0.05)$ in comparison between groups. (Table 4).

Table 4: Shows the value of hemoglobin for bladder cancer patients according to stage and grade of tumor.

\begin{tabular}{|c|c|c|c|c|c|c|}
\hline \multicolumn{2}{|c|}{ Dependant variable } & $\begin{array}{l}\text { (I) Stage of } \\
\text { tumor }\end{array}$ & $\begin{array}{l}\text { (J) Stage of } \\
\text { tumor }\end{array}$ & $\begin{array}{l}\text { Mean Difference } \\
\text { (I-J) }\end{array}$ & Std. Error & Sig. \\
\hline \multirow{15}{*}{ Hemoglobin } & \multirow{12}{*}{ Scheffe } & \multirow{3}{*}{$\mathrm{Ta}$} & $\mathrm{T} 1$ & -.5287 & .56285 & .829 \\
\hline & & & $\mathrm{T} 2$ & .48500 & .53032 & .841 \\
\hline & & & T3 & .99462 & .68989 & .559 \\
\hline & & \multirow{3}{*}{$\mathrm{T} 1$} & $\mathrm{Ta}$ & .52897 & .56285 & .829 \\
\hline & & & $\mathrm{T} 2$ & 1.01397 & .47228 & .210 \\
\hline & & & T3 & 1.52358 & .64634 & .143 \\
\hline & & \multirow{3}{*}{$\mathrm{T} 2$} & $\mathrm{Ta}$ & -.48500 & .53032 & .841 \\
\hline & & & $\mathrm{T} 1$ & -1.01397 & .47228 & .210 \\
\hline & & & T3 & .50962 & .61822 & .878 \\
\hline & & \multirow{3}{*}{$\mathrm{T} 3$} & $\mathrm{Ta}$ & -.99462 & .68989 & .559 \\
\hline & & & $\mathrm{T} 1$ & -1.52358 & .64634 & .143 \\
\hline & & & $\mathrm{T} 2$ & -.50962 & .61822 & .878 \\
\hline & \multirow{3}{*}{$\begin{array}{l}\text { Dunnett } \mathrm{T}(2- \\
{\text { sided })^{\mathrm{a}}}^{-}\end{array}$} & $\mathrm{Ta}$ & T3 & .99462 & .68989 & .303 \\
\hline & & $\mathrm{T} 1$ & $\mathrm{~T} 4$ & $1.52358^{*}$ & .64634 & .048 \\
\hline & & $\mathrm{T} 2$ & T5 & .50962 & .61822 & .694 \\
\hline \multicolumn{2}{|c|}{ Dependant variable } & $\begin{array}{l}\text { (I) Grade of } \\
\text { tumor }\end{array}$ & $\begin{array}{l}\text { (J) Grade of } \\
\text { tumor }\end{array}$ & $\begin{array}{c}\text { Mean Difference } \\
\text { (I-J) }\end{array}$ & Std. Error & Sig. \\
\hline \multirow{8}{*}{ Hemoglobin } & \multirow{6}{*}{ Scheffe } & \multirow{2}{*}{ G1 } & $\mathrm{G} 2$ & 1.24985 & .62145 & .138 \\
\hline & & & G3 & .77189 & .48524 & .287 \\
\hline & & & G1 & -1.24985 & .62145 & .138 \\
\hline & & GL & G3 & -.47716 & .52352 & .660 \\
\hline & & & G1 & -.77189 & .48524 & .287 \\
\hline & & G3 & $\mathrm{G} 2$ & .47796 & .52352 & .660 \\
\hline & Dunnett T(2- & G1 & G3 & .77189 & .48524 & .212 \\
\hline & sided) $^{\mathrm{a}}$ & G2 & G3 & -.47796 & .52352 & .587 \\
\hline & Dunr & *. The mean & $\begin{array}{l}\text { ce is significal } \\
\text { s a control, an }\end{array}$ & $\begin{array}{l}\text { the } 0.051 \text { level } \\
\text { npare all the group }\end{array}$ & nst it & \\
\hline
\end{tabular}

The value total leukocytic count showed a highly statistically significant association with tumor stage $(\mathrm{p}<0.003)$ and $a$ significant association $(\mathrm{p}<0.05)$ with tumor grades $\mathrm{G} 1$ and G2 versus G3 (Table 5). Platelet count was not significantly associated with tumor stage $(\mathrm{p}>0.05)$, but an association was seen between platelet count and tumor grade, specifically G2 vs. G3 ( $p=0.005)$ (Table 6). The value of neutrophil count showed a highly significant $(\mathrm{p}<0.005)$ association with both tumor grade and stage, with neutrophils counts increasing with higher tumor grade and stage (Table 7). The value of lymphocytic count showed 
a highly significant $(\mathrm{p}<0.005)$ association with tumor grade and

lymphocyte ratio also showed a highly significant $(\mathrm{p}<0.005)$ stage, with mean lymphocytic count decreasing with increasing association with tumor grade and stage (Table 9) (Figure 11-17). tumor grade and stage (Table 8). The value of neutrophil-to-

Table 5: Shows the value of total leucocytic count for bladder cancer according to stage and grade of tumor.

\begin{tabular}{|c|c|c|c|c|c|c|}
\hline \multicolumn{2}{|c|}{ Dependant variable } & $\begin{array}{l}\text { (I) Stage of } \\
\text { tumor }\end{array}$ & $\begin{array}{l}\text { (J) Stage of } \\
\text { tumor }\end{array}$ & $\begin{array}{c}\text { Mean Difference } \\
(I-J)\end{array}$ & Std. Error & Sig. \\
\hline \multirow{15}{*}{$\begin{array}{l}\text { Total Leucocytic } \\
\text { count }\end{array}$} & \multirow{12}{*}{ Scheffe } & \multirow{3}{*}{$\mathrm{Ta}$} & $\mathrm{T} 1$ & -.14224 & .90617 & .999 \\
\hline & & & $\mathrm{T} 2$ & $-3.42750^{*}$ & .85380 & .002 \\
\hline & & & T3 & $-4.28962^{*}$ & 1.11070 & .003 \\
\hline & & \multirow{3}{*}{$\mathrm{T} 1$} & $\mathrm{Ta}$ & .14224 & .90617 & .999 \\
\hline & & & $\mathrm{T} 2$ & $-3.28526^{*}$ & .76036 & .001 \\
\hline & & & T3 & $-4.14737^{*}$ & 1.04059 & .002 \\
\hline & & \multirow{3}{*}{$\mathrm{T} 2$} & $\mathrm{Ta}$ & $3.42750^{*}$ & .85380 & .002 \\
\hline & & & $\mathrm{T} 1$ & $3.28526^{*}$ & .76036 & .001 \\
\hline & & & T3 & -.86212 & .99532 & .861 \\
\hline & & \multirow{3}{*}{$\mathrm{T} 3$} & $\mathrm{Ta}$ & $4.28962^{*}$ & 1.11070 & .003 \\
\hline & & & $\mathrm{T} 1$ & $4.14737^{*}$ & 1.04059 & .002 \\
\hline & & & $\mathrm{T} 2$ & .86212 & 099532 & .861 \\
\hline & \multirow{3}{*}{$\begin{array}{l}\text { Dunnett } \mathrm{T}(2- \\
\text { sided })^{\mathrm{a}}\end{array}$} & $\mathrm{Ta}$ & T3 & $-4.28962 *$ & 1.11070 & .001 \\
\hline & & $\mathrm{T} 1$ & $\mathrm{~T} 4$ & $-4.14737^{*}$ & 1.04059 & .000 \\
\hline & & $\mathrm{T} 2$ & $\mathrm{~T} 5$ & -.86212 & .99532 & .664 \\
\hline \multicolumn{2}{|c|}{ Dependant variable } & $\begin{array}{l}\text { (I) Grade of } \\
\text { tumor }\end{array}$ & $\begin{array}{l}\text { (J) Grade of } \\
\text { tumor }\end{array}$ & $\begin{array}{c}\text { Mean Difference } \\
(I-J)\end{array}$ & Std. Error & Sig. \\
\hline \multirow{8}{*}{$\begin{array}{l}\text { Total Leucocytic } \\
\text { count }\end{array}$} & \multirow{6}{*}{ Scheffe } & \multirow{2}{*}{ G1 } & G2 & .30707 & 1.08180 & .961 \\
\hline & & & G3 & $-2.20287^{*}$ & .84469 & .037 \\
\hline & & & G1 & -.30707 & 1.08180 & .961 \\
\hline & & & G3 & $-2.51534^{*}$ & .91133 & .025 \\
\hline & & & G1 & $2.20827^{*}$ & .84469 & .037 \\
\hline & & os & G2 & $2.51534^{*}$ & .91133 & .025 \\
\hline & Dunnett T/2 & G1 & G3 & $-2.20827^{*}$ & .84469 & .020 \\
\hline & sided) $^{\mathrm{a}}$ & G2 & G3 & $-2.51534^{*}$ & .91133 & .014 \\
\hline & D & *. The mean & $\begin{array}{l}\text { nce is significal } \\
\text { s a control, an }\end{array}$ & $\begin{array}{l}\text { the } 0.051 \text { level } \\
\text { mpare all the group }\end{array}$ & inst it & \\
\hline
\end{tabular}


Table 6: Shows the value of platelets count for bladder cancer patients according to stage and grade of tumor.

\begin{tabular}{|c|c|c|c|c|c|c|}
\hline \multicolumn{2}{|c|}{ Dependant variable } & $\begin{array}{l}\text { (I) Stage of } \\
\text { tumor }\end{array}$ & $\begin{array}{l}\text { (J) Stage of } \\
\text { tumor }\end{array}$ & $\begin{array}{c}\text { Mean Difference } \\
\text { (I-J) }\end{array}$ & Std. Error & Sig. \\
\hline \multirow{15}{*}{ Platelets count } & \multirow{12}{*}{ Scheffe } & \multirow{3}{*}{$\mathrm{Ta}$} & $\mathrm{T} 1$ & 18.3862 & 24.1195 & .999 \\
\hline & & & $\mathrm{T} 2$ & -27.8500 & 22.7256 & .683 \\
\hline & & & $\mathrm{T} 3$ & 4.6462 & 29.5634 & .999 \\
\hline & & \multirow{3}{*}{$\mathrm{T} 1$} & $\mathrm{Ta}$ & -18.3862 & 24.1195 & .900 \\
\hline & & & $\mathrm{T} 2$ & -46.2362 & 20.2386 & .164 \\
\hline & & & T3 & -13.7401 & 27.6974 & .970 \\
\hline & & \multirow{3}{*}{$\mathrm{T} 2$} & $\mathrm{Ta}$ & 27.8500 & 22.7256 & .683 \\
\hline & & & $\mathrm{T} 1$ & 46.2362 & 20.2386 & .164 \\
\hline & & & T3 & 32.4962 & 26.4924 & .628 \\
\hline & & \multirow{3}{*}{$\mathrm{T} 3$} & $\mathrm{Ta}$ & -4.6462 & 29.5634 & .999 \\
\hline & & & $\mathrm{T} 1$ & 13.7401 & 27.6974 & .970 \\
\hline & & & $\mathrm{T} 2$ & -32.4962 & 26.4924 & .682 \\
\hline & \multirow{3}{*}{$\begin{array}{l}\text { Dunnett } \mathrm{T}(2- \\
{\text { sided })^{\mathrm{a}}}\end{array}$} & $\mathrm{Ta}$ & T3 & 4.6462 & 29.5634 & .996 \\
\hline & & $\mathrm{T} 1$ & $\mathrm{~T} 4$ & -13.7401 & 27.6974 & .901 \\
\hline & & $\mathrm{T} 2$ & $\mathrm{~T} 5$ & 32.4962 & 26.4924 & .421 \\
\hline \multicolumn{2}{|c|}{ Dependant variable } & $\begin{array}{l}\text { (I) Grade of } \\
\text { tumor }\end{array}$ & $\begin{array}{l}\text { (J) Grade of } \\
\text { tumor }\end{array}$ & $\begin{array}{c}\text { Mean Difference } \\
(I-J)\end{array}$ & Std. Error & Sig. \\
\hline \multirow{8}{*}{ Platelets count } & \multirow{6}{*}{ Scheffe } & \multirow{2}{*}{ G1 } & $\mathrm{G} 2$ & -30707 & 1.08180 & .073 \\
\hline & & & G3 & $-2.20287^{*}$ & .84469 & .820 \\
\hline & & \multirow{2}{*}{$\mathrm{G} 2$} & G1 & -.30707 & 1.08180 & .073 \\
\hline & & & G3 & $-2.51534^{*}$ & .91133 & .005 \\
\hline & & \multirow{2}{*}{ G3 } & G1 & $2.20827^{*}$ & .84469 & .820 \\
\hline & & & $\mathrm{G} 2$ & $2.51534^{*}$ & .91133 & .005 \\
\hline & \multirow{2}{*}{$\begin{array}{l}\text { Dunnett } \mathrm{T}(2- \\
{\text { sided })^{\mathrm{a}}}^{-}\end{array}$} & G1 & G3 & $-2.20287^{*}$ & .81169 & .773 \\
\hline & & G2 & G3 & $-2.51534^{*}$ & .91133 & .002 \\
\hline \multicolumn{7}{|c|}{ *. The mean difference is significant at the 0.051 level } \\
\hline \multicolumn{7}{|c|}{ a. Dunnett t-tests treat one group as a control, and compare all the groups against it } \\
\hline
\end{tabular}


Table 7: Shows the value of neutrophil count for bladder cancer patients according to stage and grade.

\begin{tabular}{|c|c|c|c|c|c|c|}
\hline \multicolumn{2}{|c|}{ Dependant variable } & $\begin{array}{l}\text { (I) Stage of } \\
\text { tumor }\end{array}$ & $\begin{array}{l}\text { (J) Stage of } \\
\text { tumor }\end{array}$ & $\begin{array}{c}\text { Mean Difference } \\
(I-J)\end{array}$ & Std. Error & Sig. \\
\hline \multirow{15}{*}{ Neutrophile count } & \multirow{12}{*}{ Scheffe } & \multirow{3}{*}{$\mathrm{Ta}$} & $\mathrm{T} 1$ & -1.9379 & 1.9011 & .792 \\
\hline & & & $\mathrm{T} 2$ & $-17.8500^{*}$ & 1.7912 & .000 \\
\hline & & & T3 & $-23.7692^{*}$ & 2.3302 & .000 \\
\hline & & \multirow{3}{*}{$\mathrm{T} 1$} & $\mathrm{Ta}$ & 1.9379 & 1.9011 & .792 \\
\hline & & & $\mathrm{T} 2$ & $-15.9121^{*}$ & 1.5952 & .000 \\
\hline & & & T3 & $-21.8313^{*}$ & 2.1831 & .000 \\
\hline & & \multirow{3}{*}{$\mathrm{T} 2$} & $\mathrm{Ta}$ & $17.8500^{*}$ & 1.7912 & .000 \\
\hline & & & $\mathrm{T} 1$ & $15.9121^{*}$ & 1.5952 & .000 \\
\hline & & & T3 & -5.9192 & 2.0881 & .051 \\
\hline & & \multirow{3}{*}{ T3 } & $\mathrm{Ta}$ & $23.7692^{*}$ & 2.3302 & .000 \\
\hline & & & $\mathrm{T} 1$ & $21.8313^{*}$ & 2.1831 & .000 \\
\hline & & & $\mathrm{T} 2$ & 5.9192 & 2.0881 & .051 \\
\hline & \multirow{3}{*}{$\begin{array}{l}\text { Dunnett } \mathrm{T}(2- \\
{\text { sided })^{\mathrm{a}}}\end{array}$} & $\mathrm{Ta}$ & T3 & $-23.7692^{*}$ & 2.3302 & .000 \\
\hline & & $\mathrm{T} 1$ & $\mathrm{~T} 4$ & $-21.8313^{*}$ & 2.1831 & .000 \\
\hline & & $\mathrm{T} 2$ & $\mathrm{~T} 5$ & $-5.9192 *$ & 2.0881 & .014 \\
\hline $\begin{array}{l}\text { Dependant } \\
\text { variable }\end{array}$ & & $\begin{array}{l}\text { (I) Grade of } \\
\text { tumor }\end{array}$ & $\begin{array}{l}\text { (J) Grade of } \\
\text { tumor }\end{array}$ & $\begin{array}{c}\text { Mean Difference } \\
\text { (I-J) }\end{array}$ & Std. Error & Sig. \\
\hline \multirow{8}{*}{ Neutrophile count } & \multirow{6}{*}{ Scheffe } & \multirow{2}{*}{ G1 } & $\mathrm{G} 2$ & -5.0364 & 3.3667 & .331 \\
\hline & & & G3 & $-10.4106^{*}$ & 2.6288 & .001 \\
\hline & & \multirow{2}{*}{ G2 } & G1 & 5.0364 & 3.3667 & .331 \\
\hline & & & G3 & -5.3742 & 2.8362 & .171 \\
\hline & & G3 & G1 & $10.4106^{*}$ & 2.6288 & .001 \\
\hline & & & $\mathrm{G} 2$ & 5.3742 & 2.8362 & .171 \\
\hline & \multirow{2}{*}{$\begin{array}{l}\text { Dunnett } \mathrm{T}(2- \\
\text { sided })^{\mathrm{a}}\end{array}$} & G1 & G3 & $-104106^{*}$ & 2.6288 & .000 \\
\hline & & $\mathrm{G} 2$ & G3 & -5.3742 & 2.8362 & .116 \\
\hline \multicolumn{7}{|c|}{ *- The mean difference is significant at the 0.051 level } \\
\hline \multicolumn{7}{|c|}{ a- Dunnett t-tests treat one group as a control, and compare all the groups against it } \\
\hline
\end{tabular}


Table 8: Shows the value of lymphocytic count for bladder cancer patients according to stage and grade of tumor.

\begin{tabular}{|c|c|c|c|c|c|c|}
\hline \multicolumn{2}{|c|}{ Dependant variable } & $\begin{array}{l}\text { (I) Stage of } \\
\text { tumor }\end{array}$ & $\begin{array}{l}\text { (J) Stage of } \\
\text { tumor }\end{array}$ & $\begin{array}{c}\text { Mean Difference } \\
\text { (I-J) }\end{array}$ & Std. Error & Sig. \\
\hline \multirow{15}{*}{ Neutrophile count } & \multirow{12}{*}{ Scheffe } & \multirow{3}{*}{$\mathrm{Ta}$} & $\mathrm{T} 1$ & -2.2466 & 1.7336 & .643 \\
\hline & & & $\mathrm{T} 2$ & $12.0250^{*}$ & 1.6335 & .000 \\
\hline & & & $\mathrm{T} 3$ & $17.1808^{*}$ & 2.1249 & .000 \\
\hline & & \multirow{3}{*}{$\mathrm{T} 1$} & $\mathrm{Ta}$ & 2.2466 & 1.7336 & .643 \\
\hline & & & $\mathrm{T} 2$ & $14.2716^{*}$ & 1.4547 & .000 \\
\hline & & & T3 & $19.4273^{*}$ & 1.9908 & .000 \\
\hline & & \multirow{3}{*}{$\mathrm{T} 2$} & $\mathrm{Ta}$ & $-12.0250^{*}$ & 1.6335 & .000 \\
\hline & & & $\mathrm{T} 1$ & $-142716^{*}$ & 1.4547 & .000 \\
\hline & & & T3 & 5.1558 & 1.9042 & .069 \\
\hline & & \multirow{3}{*}{$\mathrm{T} 3$} & $\mathrm{Ta}$ & $-17.1808^{*}$ & 2.1249 & .000 \\
\hline & & & $\mathrm{T} 1$ & $-19.4273^{*}$ & 1.9908 & .000 \\
\hline & & & $\mathrm{T} 2$ & -5.1558 & 1.9042 & .069 \\
\hline & \multirow{3}{*}{$\begin{array}{l}\text { Dunnett } \mathrm{T}(2- \\
{\text { sided })^{\mathrm{a}}}\end{array}$} & $\mathrm{Ta}$ & T3 & $17.1808^{*}$ & 2.1249 & .000 \\
\hline & & $\mathrm{T} 1$ & $\mathrm{~T} 4$ & $19.4273^{*}$ & 1.9908 & .000 \\
\hline & & $\mathrm{T} 2$ & T5 & $5.1558^{*}$ & 1.9042 & .020 \\
\hline \multicolumn{2}{|c|}{ Dependant variable } & $\begin{array}{l}\text { (I) Grade of } \\
\text { tumor }\end{array}$ & $\begin{array}{l}\text { (J) Grade of } \\
\text { tumor }\end{array}$ & $\begin{array}{c}\text { Mean Difference } \\
\text { (I-J) }\end{array}$ & Std. Error & Sig. \\
\hline \multirow{8}{*}{ Neutrophile count } & \multirow{6}{*}{ Scheffe } & \multirow{2}{*}{ G1 } & $\mathrm{G} 2$ & 3.5268 & 2.8522 & .468 \\
\hline & & & G3 & $8.4707^{*}$ & 2.2271 & .001 \\
\hline & & \multirow{2}{*}{$\mathrm{G} 2$} & G1 & -3.5268 & 2.8522 & .468 \\
\hline & & & G3 & 4.9439 & 2.4028 & .126 \\
\hline & & \multirow{2}{*}{ G3 } & G1 & $-8.4707^{*}$ & 2.2271 & .001 \\
\hline & & & $\mathrm{G} 2$ & -4.9439 & 2.4028 & .126 \\
\hline & \multirow{2}{*}{$\begin{array}{l}\text { Dunnett } \mathrm{T}(2- \\
\text { sided })^{\mathrm{a}}\end{array}$} & G1 & G3 & $8.4707^{*}$ & 2.2271 & .000 \\
\hline & & G2 & G3 & 4.9439 & 2.4028 & .081 \\
\hline \multicolumn{7}{|c|}{ *- The mean difference is significant at the 0.051 level } \\
\hline \multicolumn{7}{|c|}{ a- Dunnett t-tests treat one group as a control, and compare all the groups against it } \\
\hline
\end{tabular}


Table 9: Shows the value of Neutrophil-to-Lymphocyte ratio for bladder cancer patients according to stage and grade of tumor.

\begin{tabular}{|c|c|c|c|c|c|c|}
\hline \multicolumn{2}{|c|}{ Dependant variable } & $\begin{array}{l}\text { (I) Stage of } \\
\text { tumor }\end{array}$ & $\begin{array}{l}\text { (J) Stage of } \\
\text { tumor }\end{array}$ & Mean Difference (I-J) & Std. Error & Sig. \\
\hline \multirow{15}{*}{$\begin{array}{l}\text { Neutrophile to } \\
\text { Lymphocyt count }\end{array}$} & \multirow{12}{*}{ Scheffe } & \multirow{3}{*}{$\mathrm{Ta}$} & $\mathrm{T} 1$ & -.075808465273281 & .695634799502813 & 1.000 \\
\hline & & & $\mathrm{T} 2$ & $-3.006686383367512 *$ & .655432372967403 & .000 \\
\hline & & & T3 & $-6.716438861318103^{*}$ & .852643631109964 & .000 \\
\hline & & \multirow{3}{*}{$\mathrm{T} 1$} & $\mathrm{Ta}$ & .75808465273281 & .695634799502813 & 1.000 \\
\hline & & & $\mathrm{T} 2$ & $-2.930877918094232 *$ & 583704185155539 & .000 \\
\hline & & & T3 & $-6.640630396044823^{*}$ & .798824224661986 & .000 \\
\hline & & \multirow{3}{*}{$\mathrm{T} 2$} & $\mathrm{Ta}$ & $3.006686383367512^{*}$ & .655432372967403 & .000 \\
\hline & & & $\mathrm{T} 1$ & $2.930877918094232^{*}$ & .583704185155539 & .000 \\
\hline & & & T3 & $-3.709752477950591 *$ & .764070653252143 & .000 \\
\hline & & \multirow{3}{*}{$\mathrm{T} 3$} & Ta & $6.716438861318103^{*}$ & .852643631109964 & .000 \\
\hline & & & $\mathrm{T} 1$ & $6.640630396044823^{*}$ & .798824224661968 & .000 \\
\hline & & & $\mathrm{T} 2$ & 3.709752477950591* & .764070653252143 & .000 \\
\hline & \multirow{3}{*}{ 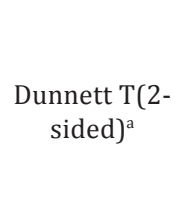 } & $\mathrm{Ta}$ & T3 & $-6.716438861318103^{*}$ & .852643631109964 & .000 \\
\hline & & $\mathrm{T} 1$ & $\mathrm{~T} 4$ & $-6.64063039604423^{*}$ & .798824224661968 & .000 \\
\hline & & $\mathrm{T} 2$ & $\mathrm{~T} 5$ & $-3.709752477950591 *$ & .764070653252143 & .000 \\
\hline $\begin{array}{l}\text { Dependant } \\
\text { variable }\end{array}$ & & $\begin{array}{l}\text { (I) Grade of } \\
\text { tumor }\end{array}$ & $\begin{array}{l}\text { (J) Grade of } \\
\text { tumor }\end{array}$ & Mean Difference (I-J) & Std. Error & Sig. \\
\hline \multirow{8}{*}{$\begin{array}{l}\text { Neutrophile to } \\
\text { Lymphocyt count }\end{array}$} & \multirow{6}{*}{ Scheffe } & \multirow{2}{*}{ G1 } & G2 & -1.067505753932009 & .987141129985743 & .559 \\
\hline & & & G3 & $-2.624337691239761 *$ & .770777986499315 & .004 \\
\hline & & \multirow{2}{*}{ G2 } & G1 & -1.067505753932009 & .987141129985743 & .559 \\
\hline & & & G3 & -1.556831937307751 & .831590924387040 & .179 \\
\hline & & \multirow{2}{*}{ G3 } & G1 & $-2.624337691239761^{*}$ & .770777986499315 & .004 \\
\hline & & & G2 & -1.556831937307751 & .831590924387040 & .179 \\
\hline & \multirow{2}{*}{$\begin{array}{l}\text { Dunnett T(2- } \\
\text { sided })^{\mathrm{a}}\end{array}$} & G1 & G3 & $-2.624337691239761^{*}$ & .770777986499315 & .002 \\
\hline & & G2 & G3 & -1.556831937307751 & .831590924387040 & .122 \\
\hline \multicolumn{6}{|c|}{ *- The mean difference is significant at the 0.051 level } & \\
\hline
\end{tabular}




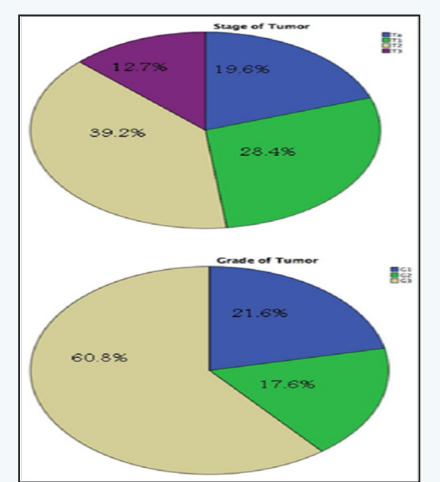

Figure 11: Descriptive Statistics of stage and grade of tumor.

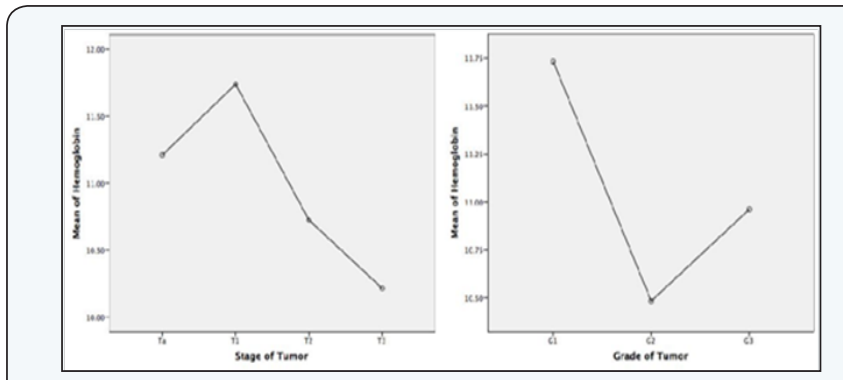

Figure 12: Mean Plot of hemoglobin.

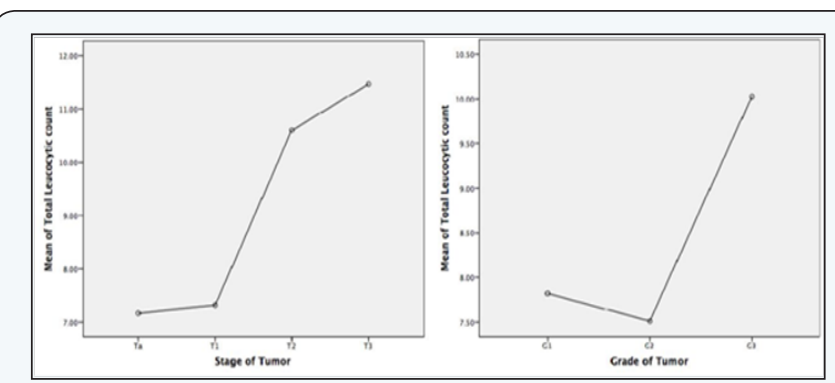

Figure 13: Mean Plot of leukocytic count.

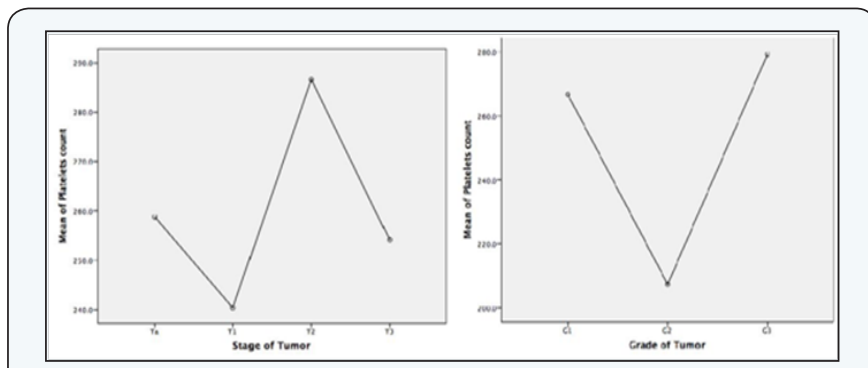

Figure 14: Mean Plot of platelets count.

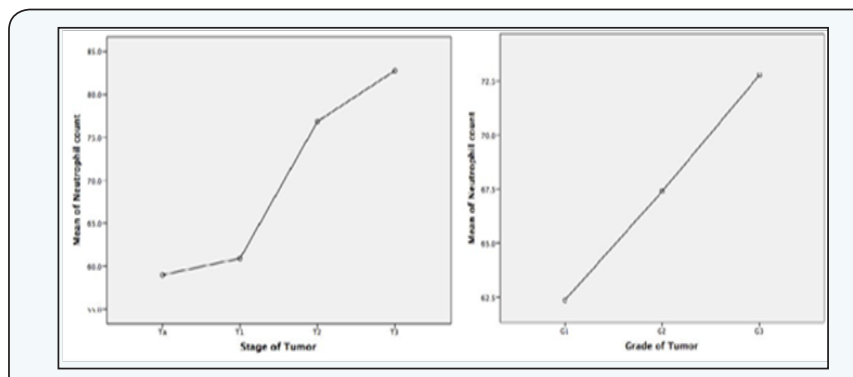

Figure 15: Mean Plot of neutrophil count.
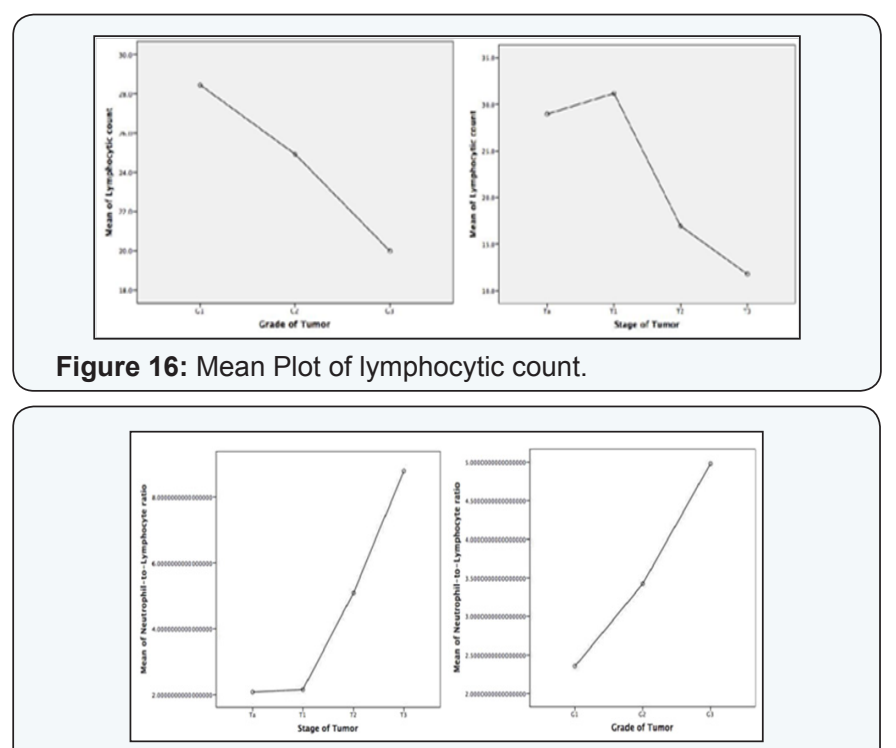

Figure 17: Mean Plot of neutrophil-to-lymphocyte ratio.

\section{Discussion}

Bladder cancer is a common tumor in the urinary tract and is the ninth most prevalent cancer around the world. Approximately $90 \%$ of bladder cancers are urothelial carcinomas (UC) and 75$85 \%$ of UC are non-muscle invasive, while $15-25 \%$ are muscleinvasive. Treatment of UC depends on pathological behavior of the tumor and optimum management of bladder cancer is guided by accurate staging, for which pathological analysis is the gold standard [2]. There is increasing evidence that host inflammatory responses play a critical role in carcinogenesis, with inflammatory cells and innate immune system signaling molecules being involved in tumor progression [46]. This systemic inflammatory response leads to changes in relative levels of circulating leukocytes, providing a means to measure this response, in addition to circulating acute-phase proteins, e.g., C-reactive protein, fibrinogen, ferritin, albumin, etc [47]. In this present study, we examined the predictive values of peripheral blood parameters for bladder cancer.

We found that hemoglobin level generally did not differ significantly $(p>0.05)$ between groups of tumor stage and grade; yet hemoglobin level was significantly lower in T3 patients compared to patients with T1disease $(\mathrm{p}<0.05)$ by using Dunnett test. Probable explanation for this study finding is what's called anemia of chronic disease. Anemia of chronic disease is a blood disorder that refers to anemia found in people with certain long-term medical conditions, such as cancers. It is a common problem for cancer patients and sometimes results from the therapies used to suppress or control tumors. Approximately one-third of cancers have anemia [48]. The anemia of cancers is caused by stimulation of the cellular immune system and inflammatory changes, which stimulate the production of chemicals called cytokines and affect both red cell production and survival. Several cytokines, including tumor necrosis factor 
(TNF), Interferon Gamma and Interleukin-1 (IL-1), can suppress bone marrow production (erythropoiesis) by affecting red cell production [34]. Patients with higher-stage bladder cancer may be more likely to be affected by these mechanisms.

In the study by Celik et al, the authors retrospectively evaluated the data collected from 639 patients who underwent TURBT surgery and The primary efficacy endpoint was the effect of preoperative anemia status on cancer-specific and overall survival. Independent t-test and chi-square analyses were performed to assess the effects of anemia on oncologic outcomes. Survival was estimated by using the Kaplan-Meier test. There were 118 (36.9\%) and 202 (63.1\%) patients in the anemia (Group-1) and non- anemia groups (Group-2), respectively. The median follow-up duration was 68 months. Anemia was associated with decreased overall survival $(<0.001)$. Comparison between cancer-specific survival of two groups did not show any statistically significant difference $(p=0.17)$. Preoperative anemia status of bladder cancer patients according to World Health Organization classification is associated with decreased overall survival, but not with cancer-specific survival.

Total leukocytic counts in our cohort of patients were significantly associated with tumor stage and grade $(p<0.003)$ when comparing between stages Ta and T2, T3 and $(\mathrm{p}<0.05)$ when comparingbetween grades G1 and G2, G3. Our results don't agree with a previous study by Al-Muhammadi et al who examined the relationship between leukocytic count and bladder cancer. Their results showed no significant associations between TLC and tumor stage or grade, and this may be attributed to the fact that the majority of their patients were low-stage. The value of platelets count showed insignificantly changed $(p>0.05)$ in comparison between stages, but a highly significant $(p<0.005)$ in comparison between G2 and G3 of tumor. In contrast, there was an inconsistency between our results and what was stated by [49] about the rare condition of paraneoplastic syndrome of bladder cancer. Paraneoplastic syndromes are defined as nonmetastatic systemic effects that accompany malignant disease. These syndromes may occur in up to $10-15 \%$ of malignancies. A few paraneoplastic syndromes have been reported in metastatic transitional cell carcinoma including hypercalcemia, thrombocytosis, eosinophilia, and leukemoid reaction. Leukemoid reaction has rarely been reported in patients with primary bladder carcinomas.

The values of neutrophil count, lymphocyte count and neutrophil-to-lymphocyte ratio all showed a highly significant association with tumor stage and grade $(\mathrm{p}<0.005)$ in comparison between groups. Our results confirmed that NLR can be an independent predictor of MIBC. NLR was first proposed as a simple index to assess the systemic inflammatory response in critically ill patients. It has the advantage over other markers of inflammation on the basis of low cost and ease of access, given that it comprises components of the routine full blood count assay, and can easily be performed prior to cystoscopy or TURBT surgery.
The association between NLR and invasive disease is complex and remains to be elucidated. A high NLR is likely to reflect an increased neutrophil-dependent inflammatory reaction and decreased lymphocyte-mediated anti-tumor immune response [50]. Our results agree with previous studies that have examined the relationship between NLR and bladder cancer staging. The consensus finding in these studies was elevated NLR in MIBC as compared to NMIBC. A study was conducted in Turkey on 216 patients who underwent transurethral resection of the bladder tumor, in the NIMBC group, $149(77.6 \%)$ of them have (range 0.08-16.72, 95 \% CI 1.67-2.97).

In terms of NLR, there was a statistically [51]. Another study [52], examined 198 patients: NMIBC $(n=162), \operatorname{MIBC}(n=36)$ and the values of NLR were found as $4.14 \pm 2.76$ and $3.36 \pm 2.88$, respectively $(\mathrm{p}=0.03)$ and they concluded that if the NLR value is greater than 3.96 , Ta-T1 tumors are likely to be invasive by $50 \%$. Furthermore, the aim of our study was to assess the relationship between peripheral blood parameters and stage and grade of urinary bladder cancer and differentiate muscleinvasive bladder cancer from non-muscle invasive disease. The groups were separated into NMIBC (Ta/T1) and MIBC (T2+). It is noted that muscle-invasive, or $\mathrm{T} 2+$ disease does include a wide range of disease. This can include cancer that has invaded the muscularis propria (T2), up to adjacent structures (T4), such as the prostate, vagina or pelvic wall, and it is likely that the systemic inflammatory response increases with tumor stage. There are limitations to our study. First, this is a single-institution observational study. Second, while patients with concurrent inflammatory conditions (e.g. infection, hematological disorder) were omitted, the confounding effect of these cannot be completely excluded. Finally, we wished to expand the study by measuring additional markers of inflammation in this population such as C-reactive protein (CRP) and ESR.

\section{Summary and Conclusion}

The current study is a prospective cohort study to assess the relationships between peripheral blood parameters and stage and grade of disease in patients with urothelial cancer of the urinary bladder. The study was conducted in Kasr Alainy hospital, Urology department on 102 patients diagnosed with bladder cancer. Preoperative blood samples were taken before the first cystoscopic examination to assess the relationship between peripheral blood parameters and stage and grade of the cancer of urinary bladder. Patients were grouped as having a non-muscle-invasive or muscle-invasive urothelial carcinoma according to pathology reports. In this present study, we examined the predictive values of various blood parameters for bladder cancer stage and grade. Our results confirmed that hemoglobin level had no significant association $(p>0.05)$ with stage or grade groups. Total leukocytic count was significantly lower $(\mathrm{p}<0.003)$ in stageTa compared to stagesT2 and T3, and a significantly lower $(\mathrm{p}<0.05)$ in grades $\mathrm{G} 1$ and $\mathrm{G} 2$ compared to G3 tumors. 
Platelet count was not significantly associated with tumor stage $(p>0.05)$, but an association was seen between platelet count and tumor grade, specifically G2 vs. G3 ( $p=0.005$ ). The values of neutrophil count, lymphocyte count and neutrophilto-lymphocyte ratio all showed highly statistically significant differences $(p<0.005)$ between tumor stage and grade groups. In conclusion, it would appear that the systemic inflammatory response parameters were strongly associated with stage and grade in patients with bladder cancer. The role of the systemic inflammatory response in determining disease-specific survival in patients with bladder cancer is worthy of further study to establish its value as a prognostic factor. NLR is an independent predictor of muscle-invasive disease and may provide a simple, cost-effective and easily measured marker for MIBC. It can be performed at the time of diagnostic cystoscopy, thereby assisting in the planning of further treatment and follow-up, including tumor resection and provision of intravesical therapy [53-77].

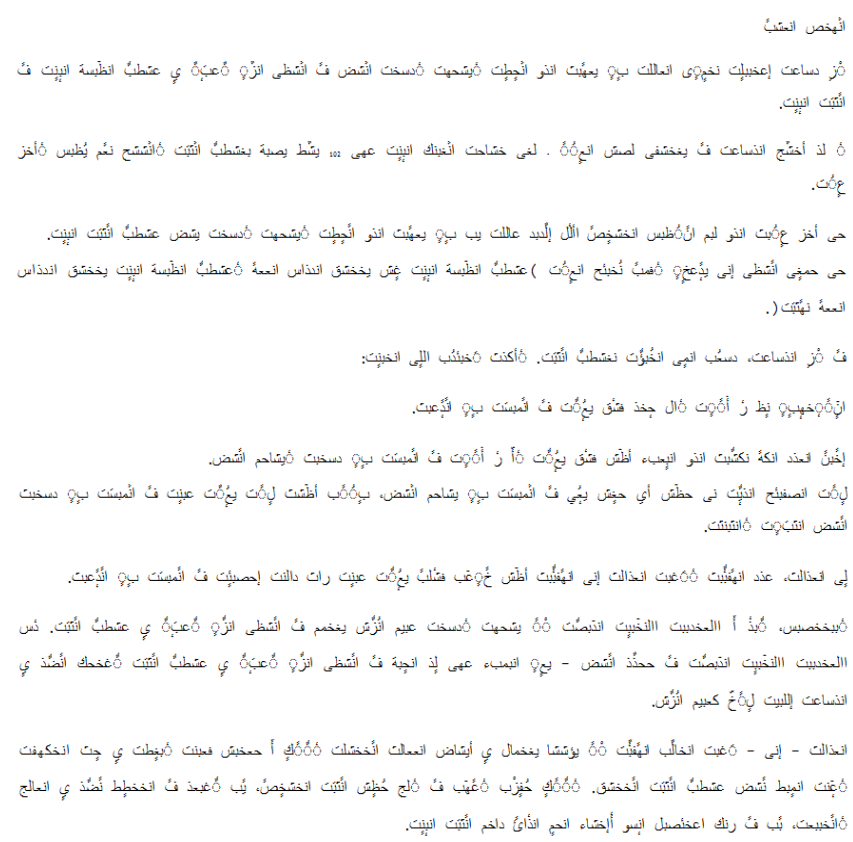

\section{Acknowledgement}

"First of all, I am deeply thankful to GOD by the grace of whom this work was possible". I wish also to express my sincere gratitude and thanks to Prof. Dr. Ashraf AboulEla, Professor of Urology, Faculty of Medicine, Cairo University, for this kind supervision, sincere encouragement, valuable advice and instructions throughout this work. It is my pleasure to express my deepest gratitude and sincere thanks to Prof. Dr. Ashraf Mosharafa, Assistant Professor of Urology, Faculty of Medicine, Cairo University, for his generous concern, sincere supervision, valuable suggestions and cooperation. To this, I will always be grateful. My deepest gratitude, appreciation and thanks to Dr. Ayman Kasem, Lecturer of urology, Faculty of Medicine, Cairo University, for his sincere supervision, cooperation and continuous support, saving no effort or time in reading each word in this work.

\section{References}

1. Jaeger N, Radeke HW, Adolphs HD, Penkert A, Bertermann H, et al (1986). Value of intravesical sonography in tumor classification of bladder carcinoma. Eur Urol 12(2): 76-84.

2. Ferlay J ,Shin HR, Bray F (2010) Cancer Incidence and Mortality Worldwide: International Agency for Research on Cancer.

3. Sengupta N, Siddiqui E, Mumtaz FH (2004) Cancers of the bladder. J R Soc Health 124: 228-229.

4. Wingo PA, Tong T, Bolden S (1995) Cancer Statistics. Cancer J Clin 45(1): 8-30.

5. Costello AJ, Tiptaft RC, England HR (1984) Squamous cell carcinoma of bladder urology. 23: 234.

6. Koss LG (1975) Tumors of the urinary bladder. In Atlas of tumor pathology, $2^{\text {nd }}$ series, fascicle II. Washington, DC, Armed Forces Institute of Pathology p. 1.

7. Trias I, Algaba F, Condom E, Español I, Seguí J, et al. (2001) Small cell carcinoma of the urinary bladder. Presentation of 23 cases and review of 134 published cases. Eur Urol 39(1): 85-90.

8. Hanahan D, Weinberg RA (2011) Hallmarks of cancer: the next generation. Cell 144(5): 646-674.

9. Grivennikov SI, Greten FR, Karin M (2010) Immunity, inflammation, and cancer. Cell 140(6): 883-899.

10. Guthrie GJ, Charles KA, Roxburgh CS, Horgan PG, McMillan DC, et al (2013) The systemic inflammation-based neutrophil-lymphocyte ratio: experience in patients with cancer. Crit Rev Oncol Hematol 88(1): 218-230.

11. Templeton AJ, McNamara MG, Šeruga B, Vera-Badillo FE, Aneja P, et al. (2014) Prognostic role of neutrophil-to-lymphocyte ratio in solid tumors: a systematic review and meta-analysis. J Natl Cancer Inst 106(6): dju124.

12. Reuter VE (2006) The pathology of bladder cancer. Urology 67 (3 Suppl 1): 11-117.

13. Ro JY, Ayala AG, El-Naggar A (1987) Muscularis mucosa of urinary bladder: importance for staging and treatment. Am J Surg Pathol 11(9): 668-673.

14. Epstein JI, Amin MB, Reuter VR, Mostofi FK (1998) The World Health Organization/International Society of Urological Pathology consensus classification of urothelial (transitional cell) neoplasms of the urinary bladder. Bladder Consensus Conference Committee. Am J Surg Pathol 22(12): 1435-1448.

15. Mostofi FK (1954) Potentialities of bladder epithelium. J Urol 71(6): 715-714.

16. Edwards PD, Hurm RA, Jaeschke WH (1972) Conversion of cystitis glandularis to adenocarcinoma. J urol 108(4): 568-570.

17. Koss LG, Espranza MT, Robbin MA (1974) Mapping cancerous and precancerous bladder changes: A study of urothelium in ten surgically removed bladder. JAMA 227(3): 281-286.

18. Althausen AF, Prout GF Jr, Daly JJ (1976) Non invasive papillary carcinoma of the bladder associated with carcinoma in situ. J Urol 116(5): 575-580.

19. Murphy WM, Soloway MS (1982) Urothelial dysplasia (Review). J Urol 127: 849-854.

20. Mostofi FK, Sobin LH, Torloni H (1973) Histological typing of urinary tumors. World Health Organization, Geneva 6: 193.

21. Epstein JI, Eble JN, Sesterhenn I, Sauter G (2004) World Health Organization Classification of Tumors, Pathology and Genetics of 
Tumors of the Urinary System and Male Genital Organs. IARC Press, Lyon, France pp. 93.

22. El-Bolkainy MN, Mokhtar NM, Ghoneim MA, Hussein MH (1981) The impact of schistosomiasis on pathology of bladder carcinoma. Cancer 48(12): 2643-2648.

23. Ghoneim MA, Awad HK (1980) Results of treatment in carcinoma of the bilharzial bladder. J Urol; 123(6): 850-852.

24. Bahnson RR (1997) Squamous cell carcinoma of bladder. J Urol 157(6): 2115.

25. Kantor AF, Hartge P, Hoover RN, Fraumeni JF (1988) Epidemiological characteristics of squamous cell carcinoma and adenocarcinoma of the bladder. Cancer Res 48: 3853-3855.

26. Holck S, Jørgensen L (1983) Verrucous carcinoma of urinary bladder. Urology 22(4): 435-437.

27. Blackmore CC, Ratcliffe NR, Harris RD (1995) Verrucous carcinoma of the bladder. Abdomen Imaging 20(5): 480-482.

28. Newman DM, Brown JR, Jay AC, Pontius EE (1968) Squamous cell carcinoma of the bladder. J Urol 100(4): 470-473.

29. Faysal MH (1981) Squamous cell carcinoma of the bladder. J Urol 126(5): 598-599.

30. Manunta A, Vincendeau S, Kiriakou G, Lobel B, Guillé F (2005) Nontransitional cell bladder carcinomas. BJU Int 95(4): 497-502.

31. Nielsen K, Nielsen KK (1983) Adenocarcinoma in exstrophy of the bladder-the last case in Scandinavia, a case report and review of the literature. J Urol 130(6): 1180-1182.

32. Choi H, Lamb S, Pintar K (1984) Primary signet-ring cell carcinoma of the urinary bladder. Cancer 53: 1985-1990.

33. Millikan R, Dinney C, Swanson D, Sweeney P, Ro JY, et al. (2001) Integrated therapy for locally advanced bladder cancer: final report of a randomized trial of cystectomy plus adjuvant M-VAC versus cystectomy with both preoperative and postoperative M-VAC. J Clin Oncol 19: 4005-4013.

34. Stone J, Richardson A, Ream E, Smith AG, Kerr DJ, et al. (2000) Cancer Related Anemia: Inevitable, Unimportant and Untreatable? Results of a multi-centre patient survey. Ann Oncol 11(8): 971-975.

35. Maton D, Hopkins J, McLaughlin ChW, Johnson S, Warner MQ, et al (1997) Human Biology and Health. Englewood Cliffs, Prentice Hall, New Jersey, US.

36. Ruka W, Rutkowski P, Kaminska J, Rysinska A, Steffen J (2001) Alterations of routine blood tests in adult patients with soft tissue sarcomas: Relationships to cytokine serum levels and prognostic significance. Ann Oncol 12(10): 1423-1432.

37. Laki K (1972) Our ancient heritage in blood clotting and some of its consequences. Ann N Y Acad Sci. 202: 297-307.

38. Cho DS, Kim SJ, Lee SH, Ahn HS, Kim YS, et al. (2011) Prognostic significance of preoperative C-reactive protein elevation and thrombocytosis in patients with non-metastatic renal cell carcinoma. Korean J Urol 52(2): 104-109.

39. Lin MS, Huang JX, Zhu J, Shen HZ (2012) Elevation of platelet count in patients with colorectal cancer predicts tendency to metastases and poor prognosis. Hepatogastroenterology 59(118): 1687-1690.

40. Hwang SG, Kim KM, Cheong JH, Kim HI, An JY, et al. (2012) Impact of pretreatment thrombocytosis on blood-borne metastasis and prognosis of gastric cancer. Eur J Surg Oncol 38(7):562-567.

41. Gorelick C, Andikyan V, Mack M, Lee YC, Abulafia O (2009) Prognostic significance of preoperative thrombocytosis in patients with endometrial carcinoma in an inner-city population. Int J Gynecol
Cancer 19(8): 1384-1389.

42. Potretzke A, Hillman L, Wong K, Shi F, Brower R, et al. (2014) NLR is predictive of upstaging at the time of radical cystectomy for patients with urothelial carcinoma of the bladder. Urol Oncol 32(5): 631-636.

43. Azab B, Bhatt VR, Phookan J, Murukutla S, Kohn N, et al. (2012) Usefulness of the neutrophil-to-lymphocyte ratio in predicting shortand long-term mortality in breast cancer patients. Ann Surg Oncol.; 19(1): 217-24.

44. Ohno Y, Nakashima J, Ohori M, Hatano T, Tachibana M (2010) Pretreatment neutrophil-to-lymphocyte ratio as an independent predictor of recurrence in patients with nonmetastatic renal cell carcinoma. J Urol 184(3): 873-878.

45. Gondo T, Nakashima J, Ohno Y, Choichiro O, Horiguchi Y, et al (2012) Prognostic value of neutrophil-to-lymphocyte ratio and establishment of novel preoperative risk stratification model in bladder cancer patients treated with radical cystectomy. Urology 79(5): 1085-1091.

46. Kumar R, Geuna E, Michalarea V, Guardascione M, Naumann U, et al. (2015) The neutrophil-lymphocyte ratio and its utilisation for the management of cancer patients in early clinical trials. Br J Cancer 112(7): 1157-1165.

47. Coussens LM, Werb Z (2002) Inflammation and cancer. Nature 420(6917): 860-867.

48. Gardner LB, Benz EJ (2008) Anemia of chronic diseases. Hematology: Basic Principles and Practice. $\left(5^{\text {th }}\right.$ edn). Philadelphia, Pa: Elsevier Churchill Livingstone pp. 219-228.

49. Stav K, Leibovici D, Siegel YI, Lindner A (2002) Leukemoid reaction associated with transitional cell carcinoma. Isr Med Assoc J 4(3): 223 224.

50. Paramanathan A, Saxena A, Morris DL (2014) A systematic review and meta-analysis on the impact of pre-operative neutrophil lymphocyte ratio on long term outcomes after curative intent resection of solid tumors. Surg Oncol 23(1): 31-39.

51. Kaynar M, Yıldırım ME, Badem H, Caviş M, Tekinarslan E, et al (2014) Bladder cancer invasion predictability based on preoperative neutrophil-lymphocyte ratio. Tumor Biol 35(7): 6601-6605.

52. Ceylan C, Doluoglu OG, Keleş I, Gazel E, Temuçin T, et al. (2014) Importance of the neutrophil-to-lymphocyte ratio in muscle-invasive and non-muscle invasive bladder tumors. Urologia 81(2): 120-124.

53. Bourner G, Dhaliwal J, Sumner J (2005) Performance evaluation of the latest fully automated hematology analyzers in a large, commercial laboratory setting: a 4-way, side-by-side study. Lab. Hematol 11(4): 285-297.

54. Gabay C, Kushner I (1999) Acute-phase proteins and other systemic responses to inflammation. N Engl J Med 340(6): 448-454.

55. Can C, Baseskioglu B, Yllmaz M, Colak E, Ozen A, et al. (2012) Pretreatment parameters obtained from peripheral blood sample predict invasiveness of bladder carcinoma. Urol Int 89(4): 468-472.

56. Demirtaş A, Sabur V, Akınsal EC, Demirci D, Ekmekcioglu O, et al. (2013) Can neutrophil-lymphocyte ratio and lymph node density be used as prognostic factors in patients undergoing radical cystectomy? Scientific World Journal 2013: 703579.

57. Eble JN, Sauter G, Epstein JI, Sesterheen IA (2004) Pathology and Genetics of Tumors of the Urinary System and Male Genital Organs. International Agency for Research of Cancer, France p. 94.

58. El-Sebaie M, Zaghloul MS, Howard G, Mokhtar A (2005) Squamous cell carcinoma of the bilharzial and non-bilharzial urinary bladder: a review of etiological features, natural history, and management. Int J Clin Oncol 10(1): 20-25. 
59. Hermanns T, Bhindi B, Wei Y, Yu J, Noon AP, et al. (2014) Pre-treatment neutrophil-to-lymphocyte ratio as predictor of adverse outcomes in patients undergoing radical cystectomy for urothelial carcinoma of the bladder. Br J Cancer 111(3): 444-451.

60. Heyns CF, van der Merwe A (2008) Bladder cancer in Africa. Can J Urol 15(1): 3899-3908.

61. Witjes JA, Compérat E, Cowan NC, De Santis M, Gakis G, et al. (2014) EAU guidelines on muscle-invasive and metastatic bladder cancer: summary of the 2013 guidelines. Eur Urol 65(4): 778-792.

62. Allin KH, Nordestgaard BG (2011) Elevated C-reactive protein in the diagnosis, prognosis, and cause of cancer. Crit Rev Clin Lab Sci 48(4): 155-170.

63. Kang M, Jeong CW, Kwak C, Kim HH, Ku JH (2015) The prognostic significance of the early postoperative neutrophil-to-lymphocyte ratio in patients with urothelial carcinoma of the bladder undergoing radical cystectomy. Ann Surg Oncol 23(1): 335-342.

64. Krane LS, Richards KA, Kader AK, Davis R, Balaji KC, et al. (2013) Preoperative neutrophil/lymphocyte ratio predicts overall survival and extravesical disease in patients undergoing radical cystectomy. J Endourol 27(8): 1046-1050.

65. Lee M, Kim SW, Nam EJ, Yim GW, Kim S, et al. (2011) The impact of pretreatment thrombocytosis and persistent thrombocytosis after adjuvant chemotherapy in patients with advanced epithelial ovarian cancer. Gynecol Oncol 122(2): 238-241.

66. Ljungberg B, Grankvist K, Rasmuson T (1995) Serum acute phase reactants and prognosis in renal carcinomas. Cancer 76(8): 14351439.

67. Mahmoud FA, Rivera NI (2002) The role of C-reactive protein as a prognostic indicator in advanced cancer. Curr Oncol Rep 4(3): 250255
68. Mano R, Baniel J, Shoshany O, Margel D, Bar-On T, et al. (2015) Neutrophil-to-lymphocyte ratio predicts progression and recurrence of non-muscle-invasive bladder cancer 33(2): 67 e1-7.

69. Papanicolaou DA, Wilder RL, Manolagas SC, Chrousos GP (1998) The pathophysiologic roles of interleukin-6 in human disease. Ann Intern Med 128(2): 127-137.

70. Pisani P, Bray F, Parkin DM (2002) Estimates of the world-wide prevalence of cancer for 25 sites in the adult population. Int J Cancer 97(1): 72-81.

71. Saito K, Kihara K (2011) C-reactive protein as a biomarker for urological cancers. Nat Rev Urol 8(12): 659-66.

72. Scher HI, Motzer RJ (2005) Bladder and renal cell carcinomas. Harrison's Principles of Internal Medicine, $\left(16^{\text {th }}\right.$ edn), NY, McGraw-Hill, New York, pp. 539.

73. Seah JA, Leibowitz-Amit R, Atenafu EG, Alimohamed N, Knox JJ, et al. (2015) Neutrophil-lymphocyte ratio and pathological response to neoadjuvant chemotherapy in patients with muscle-invasive bladder cancer. Clin Genitourin Cancer 13(4): e229-e233.

74. Sengupta N, Siddiqui E, Mumtaz FH (2004) Cancers of the bladder. J R Soc Health 124(5): 228-229.

75. Smith EM, Samadian S (1994) Use of the erythrocyte sedimentation rate in the elderly. Br J Hosp Med 51(8): 394-397.

76. Tefferi A, Hanson CA, Inwards DJ (2005) How to interpret and pursue an abnormal complete blood cell count in adults. Mayo Clin Proc 80(7): 923-936.

77. Viers BR, Boorjian SA, Frank I, Tarrell RF, Thapa P, et al. (2014) Pretreatment neutrophil-to-lymphocyte ratio is associated with advanced pathologic tumor stage and increased cancer-specific mortality among patients with urothelial carcinoma of the bladder undergoing radical cystectomy. Eur Urol 66(6): 1157-1164.

\section{Your next submission with Juniper Publishers} will reach you the below assets

- Quality Editorial service

- Swift Peer Review

- Reprints availability

- E-prints Service

- Manuscript Podcast for convenient understanding

- Global attainment for your research

- Manuscript accessibility in different formats ( Pdf, E-pub, Full Text, Audio)

- Unceasing customer service

Track the below URL for one-step submission https://juniperpublishers.com/online-submission.php 